J. Dairy Sci. 96:5405-5425

http://dx.doi.org/10.3168/jds.2012-6354

(C) American Dairy Science Association ${ }^{\circledR}, 2013$.

\title{
Invited review: Sustainability of the US dairy industry
}

\author{
M. A. G. von Keyserlingk, ${ }^{\star 1}$ N. P. Martin,† E. Kebreab,‡ K. F. Knowlton,§ R. J. Grant,\# M. Stephenson,Il \\ C. J. Sniffen,ף J. P. Harner III, ${ }^{* *}$ A. D. Wright, $† \dagger$ and S. I. Smithł‡ \\ *Animal Welfare Program, Faculty of Land and Food Systems, University of British Columbia, Vancouver, BC V6T 1Z6, Canada \\ †US Dairy Forage Research Center, US Department of Agriculture-Agricultural Research Service (USDA-ARS), Madison, WI 53706 \\ fDepartment of Animal Science, University of California, Davis 95616 \\ §Department of Dairy Science, Virginia Tech, Blacksburg 24061 \\ \#William H. Miner Agricultural Research Institute, Chazy, NY 12921 \\ $\|$ Center for Dairy Profitability, University of Wisconsin, Madison 53706 \\ TFencrest LLC, Holderness, $\mathrm{NH} 03245$ \\ ${ }^{* *}$ Department of Biological and Agricultural Engineering, Kansas State University, Manhattan 66506 \\ ††Department of Animal Science, University of Vermont, Burlington 05405 \\ ¥¥USDA-National Institute of Food and Agriculture, Washington, DC 20024
}

\section{ABSTRACT}

The US dairy industry has realized tremendous improvements in efficiencies and milk production since the 1940s. During this time, farm and total cow numbers have decreased and average herd size has increased. This intensification, combined with the shift to a largely urban public, has resulted in increased scrutiny of the dairy industry by social and environmental movements and increased concern regarding the dairy industry's sustainability. In response to these concerns, a group of scientists specializing in animal welfare, nutrient management, greenhouse gas emissions, animal science, agronomy, agricultural engineering, microbiology, and economics undertook a critical review of the US dairy industry. Although the US dairy system was identified as having significant strengths, the consensus was that the current structure of the industry lacks the resilience to adapt to changing social and environmental landscapes. We identified several factors affecting the sustainability of the US dairy industry, including climate change, rapid scientific and technological innovation, globalization, integration of societal values, and multidisciplinary research initiatives. Specific challenges include the westward migration of milk production in the United States (which is at odds with projected reductions in precipitation and associated limitations in water availability for cattle and crops), and the growing divide between industry practices and public perceptions, resulting in less public trust. Addressing these issues will require improved alignment between industry practices and societal values, based upon leadership from within the industry and sustained engagement

Received November 6, 2012.

Accepted May 19, 2013.

${ }^{1}$ Corresponding author: nina@mail.ubc.ca with other interested participants, including researchers, consumers, and the general public.

Key words: environment, social, economic, public attitude

\section{INTRODUCTION}

Over the past century, the US dairy industry has realized tremendous improvements in efficiencies of production (Martin and Mitra, 2001), achieved in part by investing in technology and productive assets, and paid for by economies of scale. The intensification of the industry is such that farms with more than 500 milking cows now account for $63 \%$ of the milk supply in the United States (USDA-NASS, 2012a), up from 39\% a decade ago (USDA-NASS, 2002). When combined with concerns regarding the world's population growth (Godfray et al., 2010a,b; Parker 2011; United Nations Population Division, 2012), potential pressures and associated challenges with food security, economic growth, social concerns, and environmental issues (Steinfeld et al., 2006), urgent need exists for a critical assessment of the sustainability of the US dairy industry.

The current review was performed by a group of individuals representing many aspects of the dairy industry, who met for three 2-d meetings in June 2011, January 2012, and June 2012. The paper, which arose as a consequence of our discussions, has been divided into 3 components: (1) a working definition of sustainability and a broad characterization of the present US dairy industry; (2) identification of each of the pillars of sustainability, emphasizing the current state of the dairy industry as well as identifying weaknesses, opportunities, and areas requiring more research; and (3) a discussion of the limitations of our review and general conclusions.

We recognize that many groups are attempting to address this issue. Our goal is to offer insights and pos- 
sible conclusions so that others may build upon our efforts. We encourage readers to partake in further discussions on this topic, where possible engaging a variety of academic disciplines and stakeholders. The Letters to the Editor section of this journal can be used as a vehicle to submit thoughts and opinions in response to our ideas presented below.

\section{DEFINING SUSTAINABILITY}

The word sustainability always includes an aspect that considers social values (Thompson, 1997). The current US legal definition (US Code Title 7, Section 3103) is as follows: "an integrated system of plant and animal production practices having a site-specific application that will over the long-term: satisfy human food and fiber needs, enhance environmental quality and the natural resource base upon which the agriculture economy depends, make the most efficient use of nonrenewable resources and on-farm resources and integrate, where appropriate, natural biological cycles and controls, sustain the economic viability of farm operations, and enhance the quality of life for farmers and society as a whole."

We used this definition as a framework for our discussions. The 3 pillars of sustainability (Figure 1; GNU Free Documentation License) also provided a framework, and we were guided by the Thompson (2007) conclusion that "We will never have a complete understanding of sustainability; we must always be willing and eager to think it through again."

\section{THE CURRENT STATE OF THE US DAIRY CATTLE INDUSTRY}

\section{Intensification of Dairy Production}

Advances in genetics, nutrition, and herd management have resulted in a 4 -fold increase in milk yield between 1944 and 2007 (Capper et al., 2009) and an associated reduction in numbers of both farms and cows. In 1940, there were approximately 21 million cows on 4,663,431 dairy farms in the United States, but by 1980, farm and cow numbers decreased 93 and $48 \%$, respectively, to 334,180 farms with just under 11 million cows (Blayney, 2002). Farm numbers decreased to approximately 53,000 licensed dairies in 2012 and cow numbers have decreased a further $16 \%$, leading to increases in cows per farm during this period (Figure $2 \mathrm{~A}$ and B). Milk yield averaged 2,361 kg/cow in 1950 (Blayney, 2002) compared with 9,702 kg/cow in 2011 (USDA-NASS, 2012b). Today's dairy industry produces $59 \%$ more milk with $64 \%$ fewer cows, consuming $77 \%$ less feed and $65 \%$ less water per liter of milk produced compared with dairy production in 1944 (Capper et al., 2009). Presently about $88.5 \%$ of the milk solids produced are consumed within the United States (NMPF, 2012 ), with the majority ( $81 \%$ ) by consumers living in urban areas (>50,000 people/city; US Census Bureau, 2010).

\section{Reliance on Immigrant Labor}

Employment practices are an important component of both the economic and social dimensions of sustainability. The US dairy industry relies heavily on foreignborn workers (Martin, 2002). Of about 138,000 full-time dairy farm employees nationwide, estimates indicate that 57,000 are foreign born (Rosson et al., 2009). In a national survey of 5,005 dairy farms in 17 states, $50 \%$ of farms used immigrant labor and $62 \%$ of the US milk supply came from dairy farms using immigrant labor (Rosson et al., 2009).

\section{Land Use Changes}

The structural changes within the dairy industry have affected land use. Between 1945 and 2007, cropland acreage decreased almost $10 \%$ (Nickerson et al., 2011), with the majority of today's cropland concentrated in the Northern Plains (North Dakota, South Dakota, Nebraska, and Kansas) and the Corn Belt

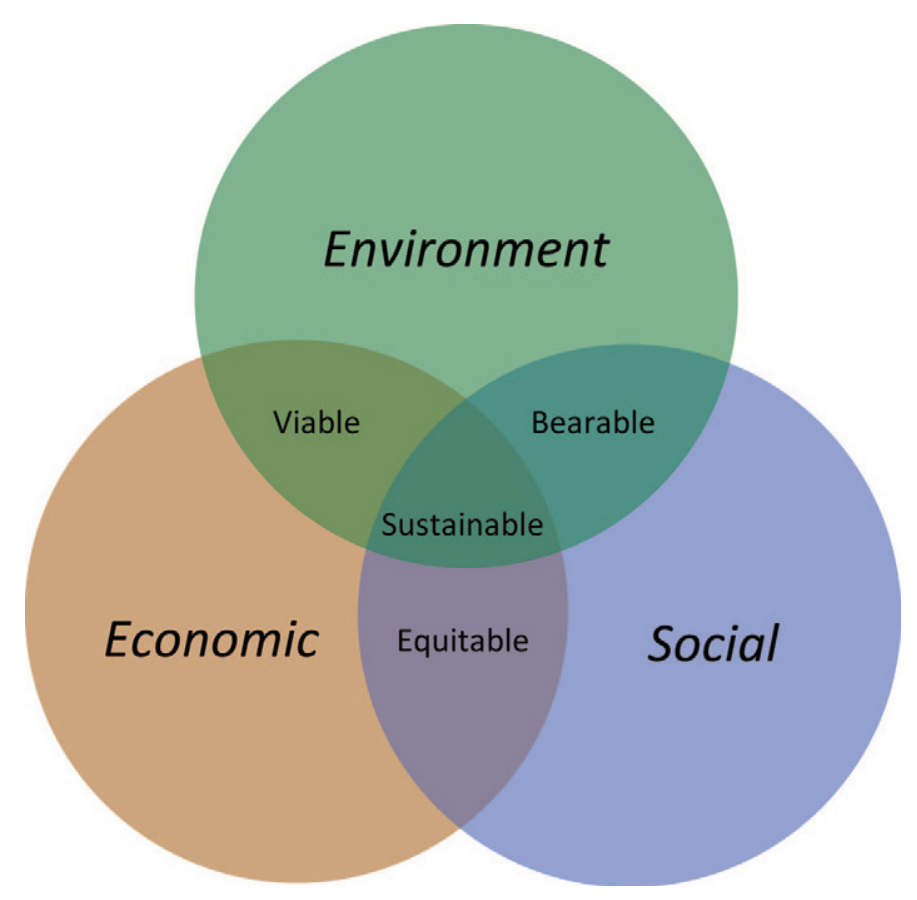

Figure 1. The 3 pillars of sustainability (used with permission under the GNU Operating System Free Documentation License). Color version available in the online PDF. 

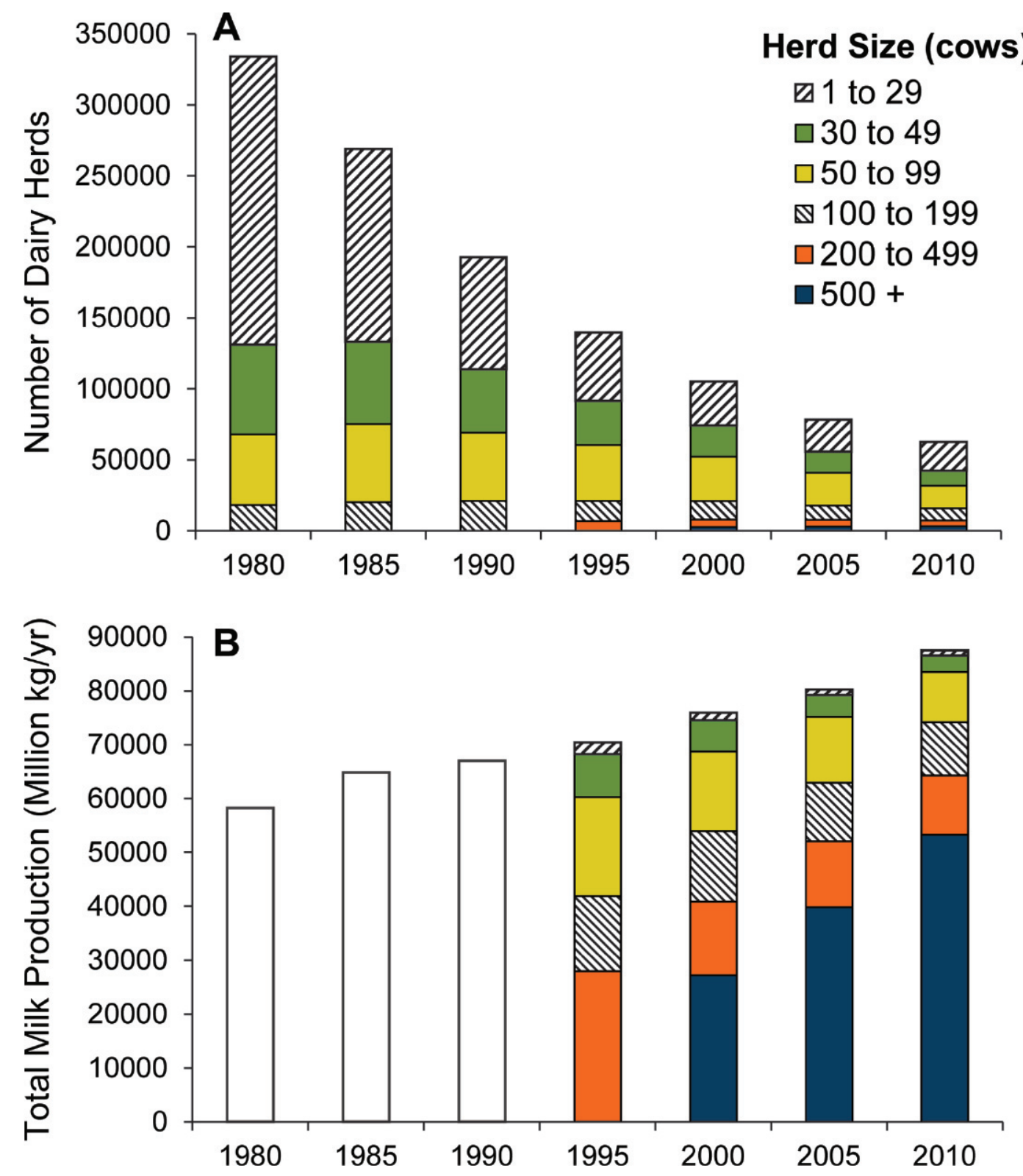

Figure 2. Change in number of dairy herds (A) and total milk produced (B) in the United States between 1980 and 2010. Data are presented by herd size. Data for total milk production by herd size were unavailable for 1980, 1985, and 1990; therefore, only total US production data are shown. Adapted from Blayney [2002); sources include United States Department of Agriculture Statistics Board, National Agricultural Statistics Service (NASS); Farms, Land in Farms and Livestock Operations; February 2007 and 2012]. Color version available in the online PDF.

(Iowa, Missouri, Illinois, Indiana, and Ohio; Figure 3). The primary use of cropland is to produce feed for animal production systems; for example, much of the grain and oilseed production is incorporated into rations to meet the dietary energy and protein requirements of food animals, respectively (CAST, 2012). Despite increases in food animal numbers within the United States (http://faostat.fao.org/site/569/ DesktopDefault.aspx?PageID=569\#ancor), land used for crop production steadily decreased from 1963 to
1981 (Nickerson et al., 2011). Of the land allocated to crop production in 1981, 17.6 million ha has since been removed from crop production entirely or allocated to the 9.8 million additional hectares for corn production. Although approximately $36 \%$ of the US corn supply is targeted for domestic feed and residual use, almost $40 \%$ of the supply is now used for ethanol production (CAST, 2012). Allocation of this decreasing land base used for crop production is a key component of any discussion of sustainability. Land use is affected by many 


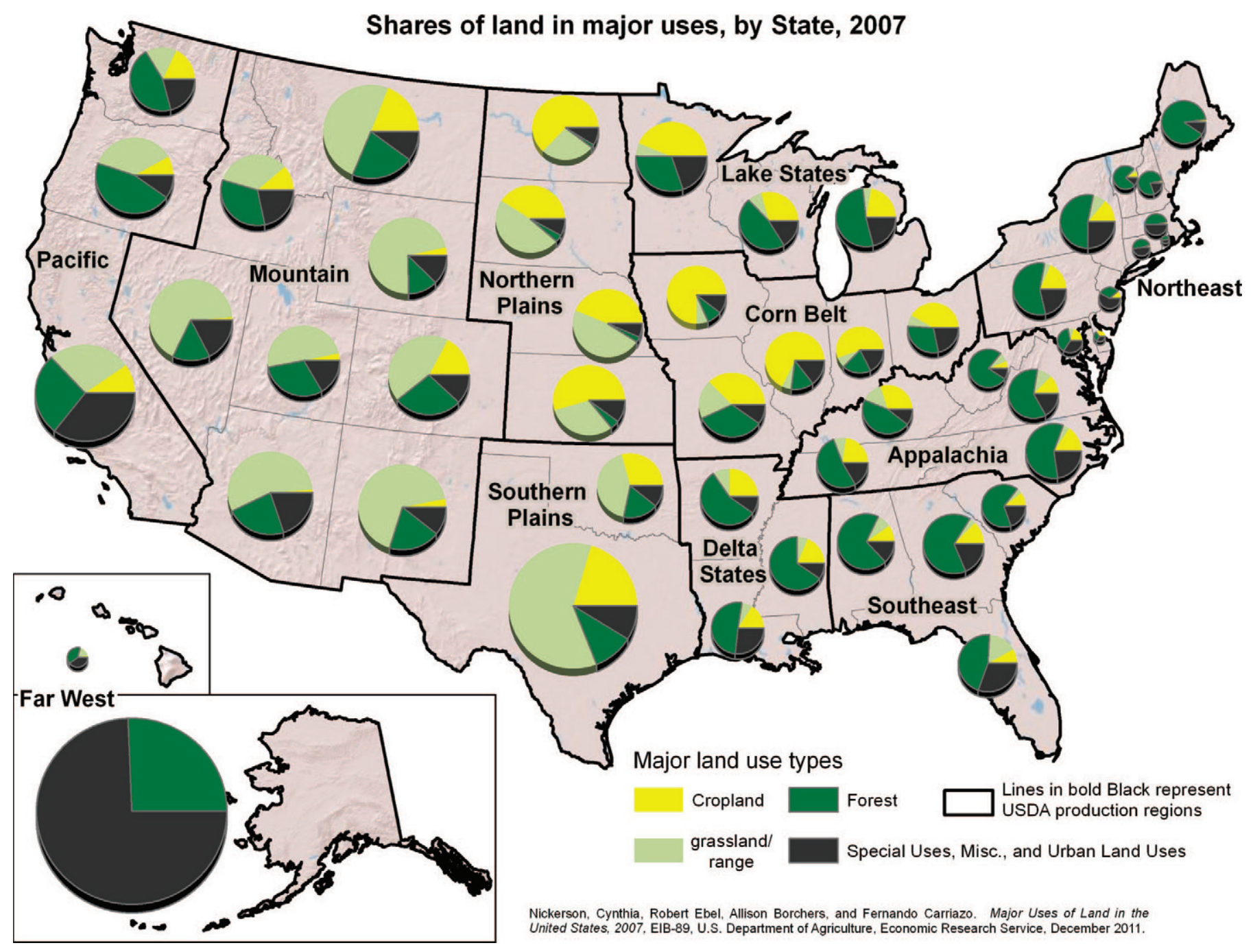

Figure 3. Major uses of land in the United States by state (Nickerson et al., 2011). Reprinted with permission from the United States Department of Agriculture (Washington, DC). Color version available in the online PDF.

factors, including government programs. An evaluation of the consequences of these programs, intended and unintended, and their impact on sustainability need to be included in program planning and review. For instance, the US Energy Independence and Security Act mandated that 36 billion gallons ( $\sim 136$ billion liters) of biofuel be produced from corn and cellulosic crops by 2022 (Pimentel et al., 2009). This policy has resulted in dramatic changes in cropland allocation; 9.8 million ha shifted to corn production in support of ethanol production (CAST, 2012), altering the relative availability and cost of commodities to support food animal agriculture. Government subsidies have encouraged farmers to grow corn; approximately $\$ 81.7$ billion in corn subsidies were paid to US farmers between 1995 and 2011 (EWG, 2012).
In 2007, almost 23 million ha (17\% of cropland) were irrigated, with $75 \%$ of this land situated in the more arid western regions; collectively, this land produced more than half of all crops sold (Nickerson et al., 2011). Total withdrawals of freshwater used for agricultural purposes peaked in the United States in 1980 and improvements in irrigation practices have resulted in a steady decrease in water usage; current estimates suggest that $9 \%$ of the freshwater withdrawals are used to produce feed for US livestock and poultry (CAST, 2012).

\section{Geography of Crop and Milk Production}

Increased specialization and concentration of livestock and crop production in different geographical 
locations within the United States has led to the net export of nutrients from major crop-producing areas to areas with a high concentration of animal agriculture (Kellogg et al., 2000). Livestock utilize nitrogen $(\mathrm{N})$ and phosphorus (P) inefficiently, excreting 60 to $80 \%$ of that consumed (ASAE, 2005). Therefore, the majority of nutrients brought onto the farm in feed stay on the farm rather than being exported in milk or meat. Although most states have experienced some regions of increase and other regions of decrease in milk production (Figure 4A), over the past $50 \mathrm{yr}$, there has been a general westward migration of dairy farms that has resulted in a growing proportion of the milk being produced in the western half of the United States (Figure $4 \mathrm{~A})$. The increasing proportion of milk produced in the west (Figure 4B; MacDonald et al., 2007) is closely intertwined with increased farm size and cow numbers.

Although the greatest changes have taken place in the Western regions, more traditional dairy areas east of the Mississippi River have not been exempt from relocation efforts by some dairy operations. For example, we note dramatic decreases in milk production in the Northeast and Florida (Figure 4A), areas that also are associated with growth in population. We suggest that factors affecting the sustainability of the dairy industry should be considered when developing policies that regulate the location (or relocation) of dairies at the state and federal levels. Relocation from regions rich in water resources to areas where water is limited would seem to be especially shortsighted (Zhou et al., 2010).

\section{Water Quality and Concentrated Animal Feeding Operations}

Increasing animal numbers and changing animal production systems has led to more stringent federal regulations for concentrated animal feeding operations (CAFO; USDA-EPA, 1999; Ribaudo et al., 2003). The 2 primary regulatory approaches used in the United States are a permit process, focused on actual or likely polluters, and a more local, water body-based approach known as the Total Maximum Daily Load program.

The US Environmental Protection Agency (EPA) directly manages the CAFO permit program in 7 of the 50 states; the remaining states have established their own regulatory programs under EPA oversight. Permits are mandated for large CAFO and for smaller farms demonstrating discharge of regulated pollutants. Court decisions in the years since 2005 have made it clear that the federal government can only require permits of farms actually discharging; size alone is not sufficient criteria. However, many states continue to determine permit eligibility primarily based on farm size. Permit conditions vary by state; effluent limits are mandated by 29 states and 37 states require nutrient management or land application plans. Groundwater monitoring is required by some states (e.g., Texas, Florida, and Oregon) and in specific regions deemed vulnerable. Similarly, regular analysis of manure and soil, inspections, and operator education are required to varying degrees by different states.

\section{Energy Use}

Modern dairies use electrical and petroleum energy sources for vehicles, pumps, motors, milking units and cooling, lighting, and heat abatement. Little peerreviewed information exists on energy use by the dairy industry. The Dairy Farm Energy Management Guide states that approximately $50 \%$ of the energy used on dairy farms (excluding crop production) is used in the milking center (milk cooling, electrical water heater, and vacuum pump) and the remainder is used in the housing area (including lighting, feeding equipment, ventilation, and manure handling; Ludington et al., 2004). This report suggests that energy use among farms varies greatly (from 300 to $1,500 \mathrm{kWh} /$ cow annually), with larger modern freestall dairies using less electrical energy per cow due to higher-efficiency milk-cooling systems, variable speed vacuum pumps, heat recovery, and other more efficient technologies. However, some technologies, such as long-day lighting and complex manure-handling systems, may result in greater energy use in larger dairies (Ludington et al., 2004).

Indirect energy use also should be considered; namely, energy used to produce, package, transport, purchase, and sell the supplies used by the dairy. Zucchetto and Bickle (1984) reported that indirect energy use accounted for $79.6 \%$ of total energy used on a 160-lactating-cow dairy in central Pennsylvania with an annual milk production of $8,081 \mathrm{~kg} / \mathrm{cow}, 160$ head of young stock and dry cows, and raising 741 ha of corn and 494 ha of alfalfa. The energy budget on that farm included fuel $(20.4 \%)$, fertilizers $(23.1 \%)$, pesticides $(15.1 \%)$, seed $(8.2 \%)$, capital $(14.8 \%)$, electricity (6.8\%), supplemental feed $(9.2 \%)$, and veterinarian supplies $(2.4 \%)$. Those authors also reported that the $\mathrm{N}$ and $\mathrm{P}$ in the manure accounted for $14 \%$ of the total equivalent energy cost in the system.

Although fuel costs within the United States are lower compared with most other countries, growing concerns regarding the possible rising costs associated with nonrenewable sources of energy have resulted in alternative energy sources slowly gaining traction within the dairy industry. Anaerobic digestion of manure, a process whereby facultative and strict anaerobes hydrolyze complex organic molecules to form volatile organic acids that are metabolized to methane $\left(\mathrm{CH}_{4}\right)$ 
A.

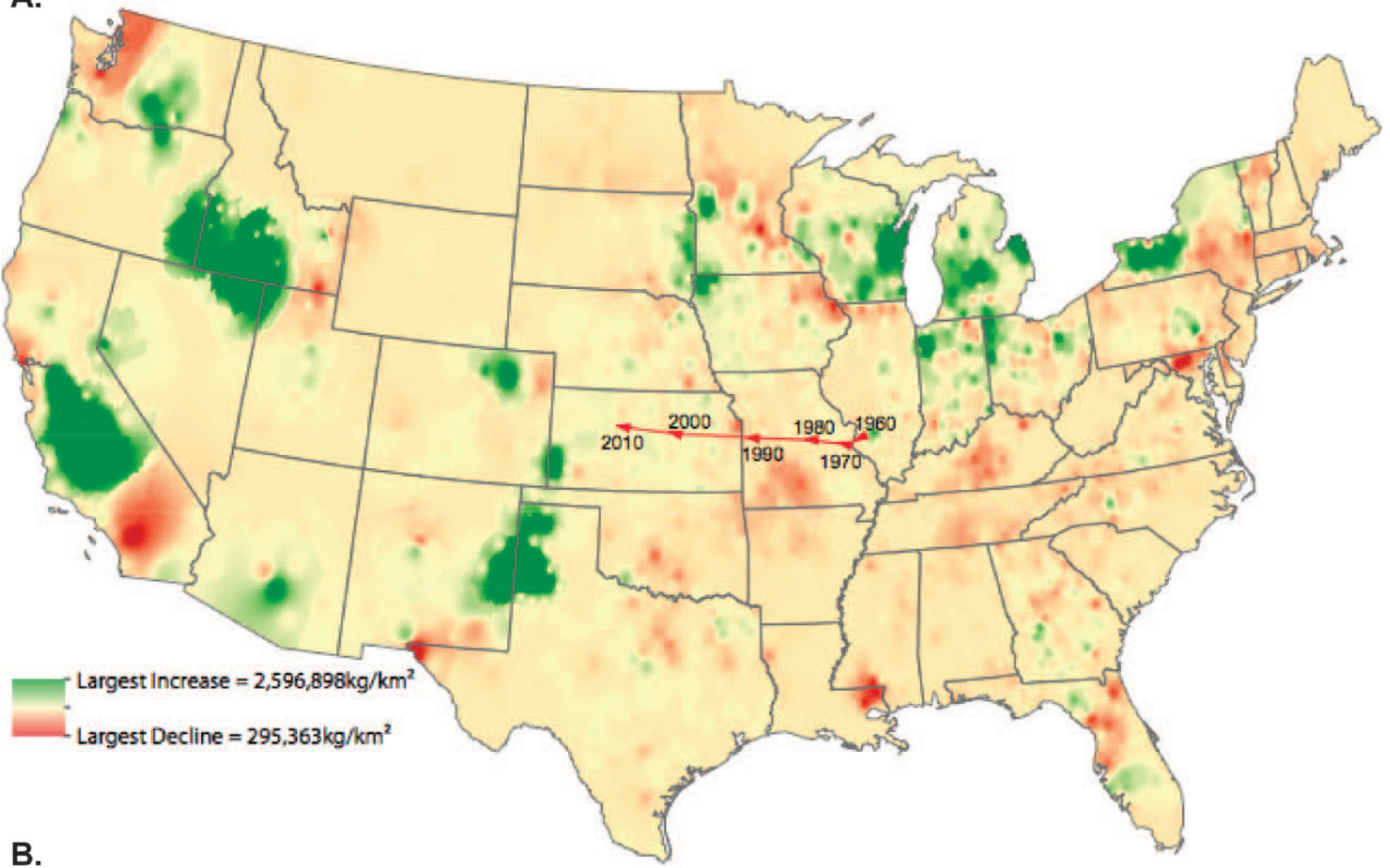

B.

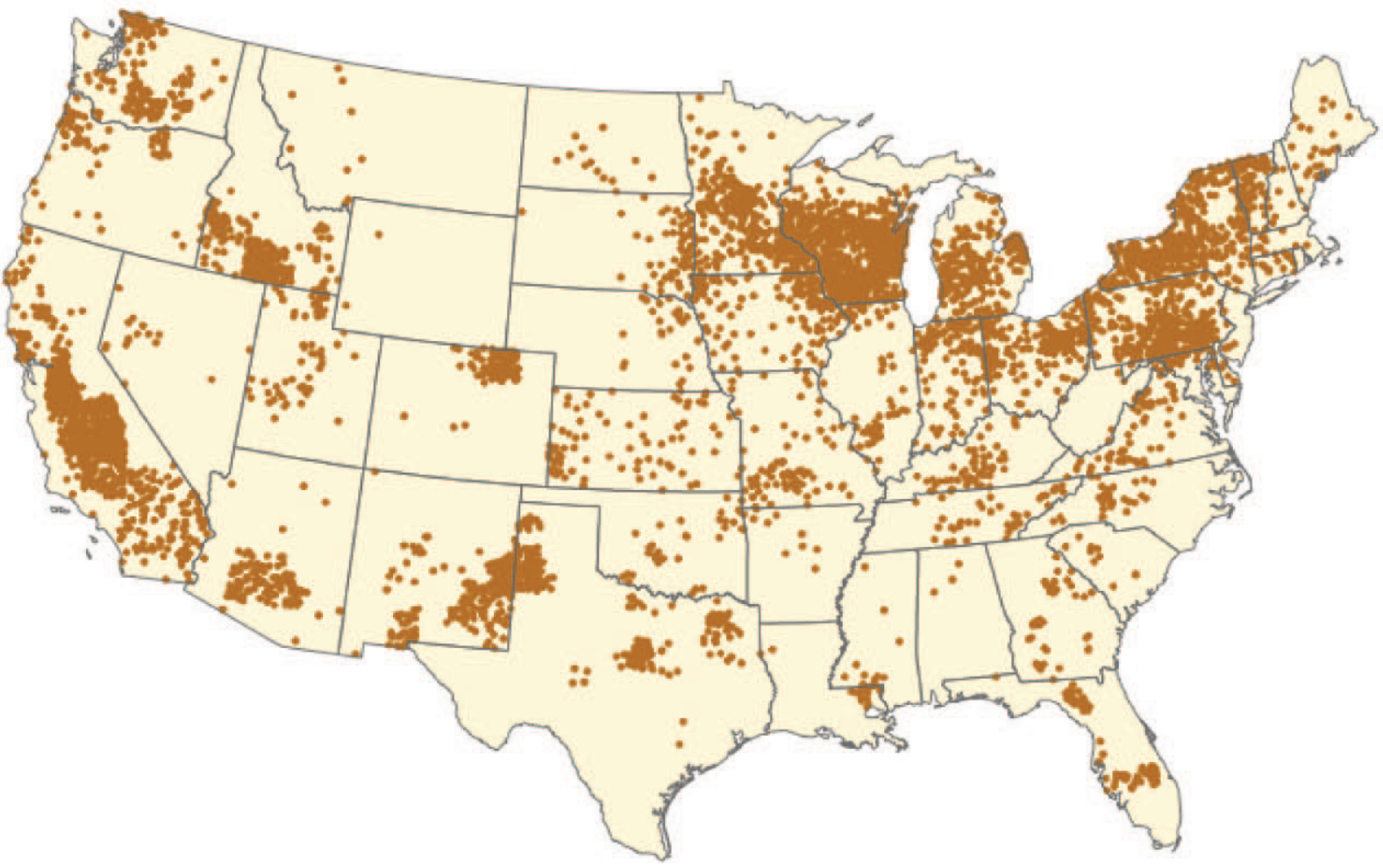

Figure 4. Changes in milk density over a recent decade (2001-2011). A: pink to red areas (lighter shading) represent declines in milk production, light to dark green areas (the darkest regions) represent increases, and beige (background) color indicates no change in milk production; the arrows (red) show the centroid (geographically weighted value) of milk production by decade from 1960 to 2010 . In general, the southeastern quadrant of the United States and the southern one-third of California have sustained losses in milk production. B: the location of dairy cows in the United States according to the 2007 agricultural census: 1 dot equals 1,500 cows. Dense clusters of cows are located in both regions of decline and increase in milk production when compared with the information provided in panel A. Color version available in the online PDF. 
and carbon dioxide $\left(\mathrm{CO}_{2}\right.$; Mergaert and Verstraete, 1987), is increasingly popular in some areas within the United States. Benefits of anaerobic digestion of dairy manure include generation of renewable energy, odor reduction, mitigation of greenhouse gas (GHG) emissions, and possible reduction in pathogenic bacteria loading during land application of manure (Kaparaju and Rintala, 2010). Although interest in generation of electricity from manure is high, economic, technological and regulatory challenges (Environmental Science Associates, 2011) will likely slow adoption.

\section{Milk Marketing and Pricing}

The forces behind increasing farm size and economies of scale have long been referred to as agriculture's "technology treadmill" (Cochrane, 1958). Milk is a commodity with properties difficult to distinguish one producer from another. This, along with many producers competing for the sale of milk, means that in today's market, little possibility exists for farmers to influence the price they receive. Thus, reducing the cost of production is considered the primary management strategy available to producers for any increase profits. Over a 15-yr period (1991 to 2006) the average milk price typically varied between $\$ 13.00$ and $\$ 14.00$ US dollars (USD) per $45.3 \mathrm{~kg}$ of milk (cwt), ranging from a minimum of $\$ 11.00$ to a maximum of $\$ 19.30$ (NAHMS, 2008). Since 2007, the US farm milk price has been reasonably competitive with other exporting countries [most notably New Zealand, Australia, and the European Union (EU)] and the United States has, thus, begun to export more milk (currently about $13 \%$ of the milk produced: NMPF, 2012).

\section{The Debate}

The intensification of animal agricultural has resulted in disruptive effects on the environment, food availability, rural populations, biodiversity, and animal welfare (Fraser, 2008; Croney and Anthony, 2011), resulting in intense criticisms of food animal industries by social, animal, and environmental protection movements. One argument used to defend the intensification of animal agriculture is that increased efficiencies will allow improved production and, thus, better potential to feed the 9 billion people in the world by 2050 (see Capper et al., 2009; but see also Hall et al., 2009; Godfray et al., 2010a). From this perspective, increased intensification is seen not as the result of being trapped on the technology treadmill, but rather as a moral good and even as part of our larger responsibility in feeding the world. Regardless, there appears to be a growing gap between farm practices and societal expectations, a gap that directly threatens the current and future sustainability of the US dairy industry. Below, we provide a frank assessment of the US dairy industry framed around the 3 pillars of sustainability: environmental, economic, and social (Figure 1).

\section{ENVIRONMENTAL ASPECTS}

Environmental concerns are often raised when discussing sustainability and these have probably received the most attention in both the academic and popular press. Little debate exists that food-animal producers experience ever-increasing competition for water, land, and energy, and that a need exists to mitigate the negative effects of food production on the environment (Thornton, 2010).

\section{Water}

Globally, agriculture is one of the greatest consumers of water, and shortages of water can have profound effects on food production (Godfray et al., 2010b; Strzepek and Boehlert, 2010). Increased population growth will increase competition for resources such as water, land, and energy among agriculture, municipalities, and industrial enterprises. Concurrent with increased use of water come the increased risks associated with contamination. Salt and nitrates are perhaps the most wide spread groundwater contaminants in the United States; salt contamination is a growing challenge in many regions of the United States, with a well-established detrimental effect on cattle (Grout et al., 2006).

Nutrient pollution of drinking water is also of concern. Recent studies undertaken in the states of California (Harter et al., 2012) and Washington (US EPA, 2012a) found that approximately 10 and $20 \%$ of public wells sampled exceeded the maximum contamination concentrations of nitrate (10 mg of nitrate-N/L), respectively. In some areas of California, with high concentrations of dairy operations, more than one-third of domestic wells exceeded the nitrate maximum contamination level (Harter et al., 2012). Nitrate problems will likely worsen and require mitigation options such as blending high-quality water and a fee on $\mathrm{N}$ fertilizer use.

A cluster of dairies located in the Yakima Valley of Washington, that in 2009 collectively owned 17,240 mature dairy cows and an additional 7,000 heifers and calves, was found to be the primary source for pharmaceutical contamination (monensin and tetracycline) in the majority of dairy source samples (US EPA, 2012a). Sources included 8 residential drinking wells, 4 dairy applications (soil samples taken from fields fertilized 
using dairy lagoon waste), 4 field samples, 10 dairy lagoons, 4 manure piles, 3 dairy supply wells, and 1 up-gradient residential drinking water well.

With population growth and increasing demand for non-farm uses of water, there is pressure for policy reform in water use, especially in more arid areas (Rosegrant et al., 2002). Irrigation is increasingly contentious as global aquifers are becoming depleted (Wada, 2012), including those in the West and Southwest regions of the United States. The continued reliance on irrigation to support intensified crop production in these more arid regions, particularly in the face of climate change, increases the risk that water will become increasingly scarce (Zhou et al., 2010). Efforts to refine irrigation practices, such as only irrigating during the night to minimize evaporation (Zhou et al., 2010), cultivation of forages that require less water, and implementation of a coordinated plan that takes into consideration all users of water in a particular region, must be made a priority.

Animal agriculture globally accounts for approximately one-third of the water footprint of human activity (Mekonnen and Hoekstra, 2012), and 98\% of the water footprint of animal production is the water required to produce feed (Shiklomanov, 2000). Feed prices are also the single largest milk-production expense (USDAERS, 2012). Similar to the carbon footprint, as efficiency of milk production increases, the water footprint is reduced (Mekonnen and Hoekstra, 2012). According to Hoekstra (2012), feeding diets containing more forages will reduce the water footprint of milk production, given that the water footprint of concentrates is 5 times greater than that of forages. We see great opportunities for innovative feeding ingredient selection and ration formulation in which the water footprint is considered.

\section{Land}

In $2007,91.3 \%$ of dairy farms made use of approximately 8 million ha of cropland and pasture, a decrease from about 10.9 million ha used in 1997 (USDA-NASS, 2009). Historically, agriculture has responded to increases in the demand for food by bringing more farmland into production, but Smith et al. (2010) showed that this is less of an option today, given projected trends in population growth. Moreover, reclamation of land for agricultural purposes comes at the expense of biodiversity and deforestation or other land-use change, and these changes may exacerbate the contribution of GHG emissions from agriculture (Godfray et al., 2010b).

As stated above, increasing competition for land will continue to come from biofuels, driven in large part by government corn subsidies. The rapid growth of biofuel production in the United States, the EU, and Brazil has important implications for the global live- stock industry. The cost of feed grains and oilseeds has increased and a large supply of biofuel by-products, such as distillers grains, has entered the market (Taheripour et al., 2011). Corn-based ethanol production in the United States is an energy-inefficient process and implementing biofuel mandates increases the cropland area, a large portion of which comes from a reduction in grazing lands (Sanderson et al., 2009) and directly competes with forage and livestock production for government-subsidized corn.

Proposed developments of ethanol plants using cellulosic feed sources target $50 \%$ of their feedstock for the plants from agriculture (crops such as corn residues, vegetable oils and animal fats, other crop residues, and energy crops), thereby causing competition for coproduct feeds used to feed animals. Whether or not the demand for corn-based ethanol production will increase and, thus, further compete for access to corn fed to cattle, is debatable. Recently, the US Department of Agriculture (USDA) Office of the Chief Economist predicted that competition for corn for ethanol production has peaked and corn production for feed will not be at risk in the long term (USDA-OCE, 2012). Governmental policy will play a key, but unpredictable, role in the future trends in biofuel production. At present, the US EPA Renewable Fuel Standard requirement forces fuel refiners to blend approximately 50 billion $\mathrm{L}$ of corn ethanol into the US motor fuel supply, which equates to approximately $40 \%$ of all US corn production. To fully elucidate the long-term effects of these types of energy policy decisions on sustainability will require an in-depth economic and environmental (harm) impact analysis.

Pasture-based production provides an opportunity to contribute to food animal production without competition with grain-based human food systems (Capper et al., 2009), especially when land used for grazing is not suitable for growing grain crops. Arable land may be better used for cropping, as land requirements for pasture-based systems are typically greater, and percow production less, than in zero-grazing dairy systems. Interestingly, a recent study reported that the water footprint appears to be the least for dairy products derived from a mixed system (the combination of a grazing and industrial production system) and a bit larger but comparable when obtained from purely grazing or industrial systems (Mekonnen and Hoekstra, 2012). We see much opportunity for the dairy industry to explore these mixed (diverse) systems, taking into consideration factors such as water availability and optimum land usage.

Grazing systems can be competitive economically. A comparison of farm enterprise records of Wisconsin grazing dairies and California confinement herds over a 
12-yr period (1998 to 2010) showed that the 2 systems had similar average costs of production $(\$ 0.23 \mathrm{USD} / \mathrm{kg}$; Kriegel, 2012). Comparisons of different systems require a multifaceted approach that recognizes the different relevant metrics within each system. For example, efficient pasture-based systems are often characterized by high milk output per unit of land, whereas confinement systems are traditionally characterized by high milk output per cow (Bargo et al., 2003). Pasture-based dairies also provide visually appealing landscapes that are valued by some citizens (Meul et al., 2012). The perceived environmental, aesthetic, and animal welfare advantages also have allowed some dairies that use pasture to take advantage of organic and other niche markets for their milk.

The limited work available to date on the use of pasture from the cow's perspective indicates that cows provided a choice between freestall housing and pasture (with no available shade) remain indoors for the most part during the day and outside at night (Legrand et al., 2009; Falk et al., 2012), again suggesting a potential advantage for mixed systems.

\section{Climate Change}

Global surface temperatures already have increased by 0.2 to $0.6^{\circ} \mathrm{C}$ since 2000 , and are projected to increase by another 1.5 to $5.8^{\circ} \mathrm{C}$ by the end of the century (IPCC, 2007). This increase in temperature will almost certainly influence regional precipitation patterns (Sanderson et al., 2009) and have dramatic consequences on human populations (Battisti and Naylor, 2009). Many climate change predictions indicate that periodic droughts will become more common and extreme rainfall events more frequent (Battisti and Naylor, 2009; Karl et al., 2009). Elevated temperatures also increase the risk of dairy cows experiencing heat stress [e.g., temperaturehumidity index $\geq 72$ (corresponding to $25^{\circ} \mathrm{C}$ and $50 \%$ relative humidity; Ravagnolo et al., 2000)]. One way of mitigating the harmful effects on cows may be to use breeds better adapted to high heat, especially for those regions such as the Southeastern United States that are prone to prolonged periods with high temperatures. Alternatively or additionally, cooling methods for cows such as evaporative cooling likely would become more prominent in areas not previously challenged with heat stress, although these methods may be considered too water- and electricity-intensive in the future.

A combination of increased periods of dry weather interspersed with larger individual rainfall events will result in extended periods of soil-moisture deficit and greater variability in soil water content. Such changes will have important consequences on grain-crop, foragecrop, and grassland production. The timing of rainfall may be more important than changes in rainfall amount in affecting crop growth and quality, forage quality, and ecosystem properties such as $\mathrm{CO}_{2}$ uptake and forage productivity.

To maintain productive crop, forage, and grassland systems in the face of these climate changes, farmers will need to manage flexible and resilient systems, and adjust quickly to environmental fluctuations. Volatile weather conditions would make it increasingly difficult to sustain cropping with limited diversity. In this context, grasslands may become a more important way to diversify farming systems (Sanderson et al., 2009). These predicted trends in temperature and precipitation indicate challenges for dairy operations with limited land base and heavy reliance on imported forage and grain nutrients, already common in the southern high plains and western United States. A warming trend for the Great Lakes states and the northeastern US dairy industry suggests that crop diversification may be beneficial.

\section{Energy}

The dairy industry has received considerable negative attention regarding its carbon footprint, particularly its reliance on nonrenewable resources. The reliance on nonrenewable energy sources is, by definition, unsustainable (Godfray et al., 2010a). Petroleum is associated with cropping and feed enterprises, including planting, fertilizing, and harvesting of crops, and mixing and delivery of feed to the housing area. Moving cows from confined housing systems to pasture-based systems would likely reduce the dependence of dairy farms on petroleum energy associated with non-milking aspects. However, many regions of the United States are not able to support grass-based animal agriculture, especially when using cows with high genetic potential for milk production.

Ironically, aspects of providing milk to young calves can be portrayed as excellent examples of both energy efficiency and inefficiency. One illustration of dairy production commonly seen in many developing countries (Das et al., 2001), where costs associated with energy use are high, has cows grazing on pasture, fertilizing the field with their own manure, and thus turning sunshine into milk (in a way that few, if any, nonruminant systems could match). In these more extensive situations, calves are often provided restricted access to their dams, nursing only twice daily for $30 \mathrm{~min}$, thus reducing the labor and energy costs associated with feeding calves individually by hand (Figure 5A) or automated milk feeding systems. A counter example, the feeding of milk replacers, common in dairy farms in many developed countries, is an energy-inefficient practice. The cow 
is mechanically milked and the milk is cooled, stored, transported, dried, transformed (by removing some components and adding others), marketed, transported back to the farm, mixed with hot water, and fed to the dairy calf; each step requires energy input (Figure 5B). Which of these illustrations most accurately reflects how the dairy industry makes use of energy will, thus, depend upon the specific practices we use, how these practices are implemented, and also on how we trade off the various components within a practice. What seems clear is that with global energy use projected to increase (IPCC, 2007), improved efficiency of energy use within the dairy industry may become increasingly important (Schade and Pimentel, 2010), especially use of energy originating from nonrenewable resources such as oil and coal.

Generation of electricity on farm through digestion of manure also would help alleviate this dependence on nonrenewable energy (Atandi and Rahman 2012). The economic viability of on-farm anaerobic digestion as an alternative energy source will depend on policies of the state or utility regulating sale and pricing of power generated from methane (Zaks et al., 2011). Net metering policies credit the electricity bills of the farmer for electricity produced at retail rates, effectively running the meter backward. In the United States, all public utilities are required to offer net metering upon request (Energy Policy Act of 2005, Public Law 109-58), but the obvious limitation is that credits are awarded only to the maximum total of the farmer's electricity bill. Key questions that influence the value to the dairy producer include whether credits can be banked when electricity production exceeds use and if those credits can be used to offset electricity use by buildings on the farm or homes. Large farms that produce excess electricity beyond their needs have, in some cases, successfully negotiated to sell electricity to the power company; we see much opportunity for this to expand. However, success will depend in part on investments in equipment and on genuine interest from the utility companies. Twenty-nine US states have renewable energy mandates in place, whereby utilities are required to produce a portion of their electricity from renewable sources (IER, 2011). However, more than half of these states are not on track to meet requirements. Some utilities also offer green pricing, voluntary programs allowing consumers to opt for renewable energy at a premium price (e.g., Vermont's successful Green Mountain Power "Cow Power" program). Cap and trade of emissions in California commenced on January 1, 2013, and the use of anaerobic digesters is one of the few approved methodologies for carbon offset (http://www. arb.ca.gov/cc/ab32/ab32.htm). The extent to which these sorts of programs are incorporated into dairy
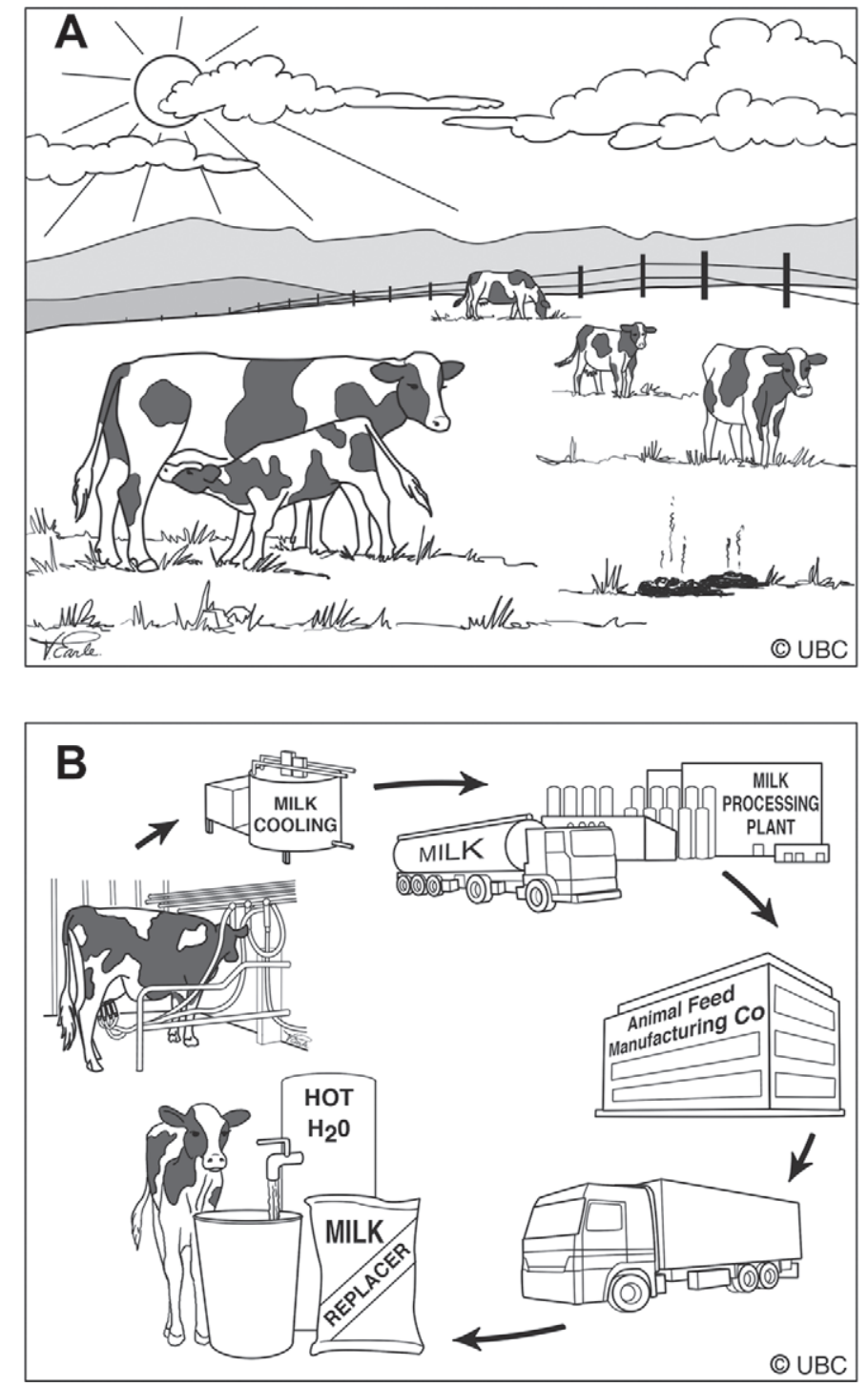

Figure 5. Illustrating the differences in energy costs associated with providing milk for dairy calves: (A) cows grazing on pasture and fertilizing the field with their own manure, thus turning sunshine into milk, and (B) rough schematic of the steps involved in making milk replacers whereby the cow is mechanically milked, the milk is cooled, stored, transported, dried, transported back to the farm, mixed with hot water, and fed to the dairy calf. Reprinted with permission by the University of British Columbia (Vancouver, BC, Canada).

production practices remains to be seen and will likely be dependent, in part, on the incentives provided to encourage early adopters that can aid in facilitating change within the industry.

Adoption of alternative renewable energy sources will depend upon energy costs. We encourage efforts to model scenarios associated with changes in energy costs, both short and long term, which may arise. For instance, removal of corn subsidies that support ethanol production and changes in fuel costs would no doubt 
have a profound impact on the use of nonrenewable energy sources.

\section{Nutrient Management}

Animal manure is typically land applied to supply nutrients for crop growth, but application in excess of crop needs results in nutrient losses and contamination of groundwater, surface water, and the air (Knowlton et al., 2004). Concentrated animal agriculture has been identified as a significant source of $\mathrm{N}$ and $\mathrm{P}$ contamination of surface water (median contribution $=6.8$ to $48 \%$ of $\mathrm{P}$ loss and 5.2 to $23 \%$ of $\mathrm{N}$ loss, depending on watershed; Smith and Alexander, 2000). Increasing public concern about water quality and increased awareness of the potential impact of concentrated livestock production has led to the development and implementation of increasingly stringent environmental regulations (Knowlton et al., 2004). A recent development is the federal requirement for states to develop watershed implementation plans (WIP) to reduce nutrient losses from farms over a planned and monitored time course. This WIP approach is an attempt by the EPA to have states more aggressively pursue and document reductions in nutrient losses. The implicit stick is that if WIP are not implemented, or do not lead to demonstrable improvements in water quality, the federal government will declare that state's program ineffective and take control. What is clear is that water quality (and usage) issues are complex and the implementation of strategies that promote sustainability must take into consideration the specific challenges present in the different geographical regions of the country. A possible solution may involve the redistribution of dairy farms across the landscape; in other words, closer proximity of the cattle to the feed and crops to facilitate better manure/ nutrient distribution and recycling options.

\section{Air Emissions}

Dairy production has an impact on the environment through air emissions (Alvarado et al., 2012). The major gas pollutants are the GHG carbon dioxide $\left(\mathrm{CO}_{2}\right)$, methane $\left(\mathrm{CH}_{4}\right)$, nitrous oxide $\left(\mathrm{N}_{2} \mathrm{O}\right)$, and oxides of nitrogen ( $\mathrm{NO}$ and $\left.\mathrm{NO}_{2}\right)$, ammonia $\left(\mathrm{NH}_{3}\right)$, hydrogen sulfide $\left(\mathrm{H}_{2} \mathrm{~S}\right)$, and volatile organic compounds (VOC). In addition to gas emissions, particulate matter, including both coarse dust and fine particles, is also released from dairy operations. The US Clean Air Act requires the EPA to set National Ambient Air Quality Standards for some of these air emissions (i.e., $\mathrm{N}_{2} \mathrm{O}$ and $\mathrm{H}_{2} \mathrm{~S}$ ) as well as particulate matter. Although most National Ambient Air Quality Standard compounds are not directly emitted from livestock operations, precursor compounds such as ammonia and VOC are emitted, which affect human health. For example, VOC in the air react with oxides of $\mathrm{N}$ and sunlight to form ozone, which affects normal lung function in many healthy humans (Kirkhorn and Garry, 2000). In addition, standards such as the Emergency Planning and Community Right-to-Know Act (EPCRA) Section 304 require farms to report $\mathrm{NH}_{3}$ and $\mathrm{H}_{2} \mathrm{~S}$ emissions if $45.3 \mathrm{~kg}$ or more of either are emitted in any given 24 -h period. The major sources of gaseous emissions in such facilities include the feed system, animal housing, manure collection, treatment and storage structures, and land application. A decade ago, the NRC (2003) highlighted the need for emission studies with focus on individual operations or sources within the animal feeding operations, but little research has been undertaken to date. We see the need for much work in this area. For example, variables that determine the amount of emissions should be evaluated with meta-analytical approaches. This will identify the effects of variables such as those related to animal production, housing management (e.g., flooring characteristics and cleaning frequency), aerobic compost management information (e.g., pile size, duration, and coverage), and anaerobic storage. In addition, this approach will allow for mitigation options to be targeted to a specific variable, allowing for targeted research to be effectively carried out to identify the best solutions needed to move forward.

Agriculture contributes $6.3 \%$ to the total GHG emissions (US EPA, 2012b), but air emissions from farms are not regulated. Most life-cycle-analysis studies show that the emission intensity from dairy production is close to $1 \mathrm{~kg}$ of $\mathrm{CO}_{2} \mathrm{Eq} / \mathrm{kg}$ of milk at farm gate or 2.4 $\mathrm{kg}$ of $\mathrm{CO}_{2} \mathrm{Eq} / \mathrm{kg}$ of fat and protein-corrected processed milk (FAO, 2010). The global average $\mathrm{CO}_{2}$ equivalent emission is about twice the US average (Milani et al., 2011). Of these emissions, $55 \%$ are associated with the raising of livestock, not including energy use (USDA, 2011). The largest contributor to on-farm emission is $\mathrm{CH}_{4}$ from enteric ruminoreticular fermentation (Hagemann et al., 2011). To the animal, enteric methane represents an energy loss up to $12 \%$ of gross energy intake (Johnson and Johnson, 1995; Van Nevel and Demeyer, $1996)$, or 10 to $35 \mathrm{~g} / \mathrm{kg}$ of DMI, and to the environment it represents a GHG 25 times more potent than $\mathrm{CO}_{2}$ (IPCC, 2006). Using global-warming potentials for a 100-yr time horizon, $\mathrm{CH}_{4}$ constitutes about one-third of global livestock GHG emissions (Steinfeld et al., 2006). Several potential mitigation actions are available for producers to consider for reducing GHG emissions from the farm (e.g., Boadi et al., 2004; Kebreab et al., 2006), including improvements in feed-conversion efficiency. Improved feed-conversion efficiency can be achieved by concentrating the nutrient density of the diet (Vande- 


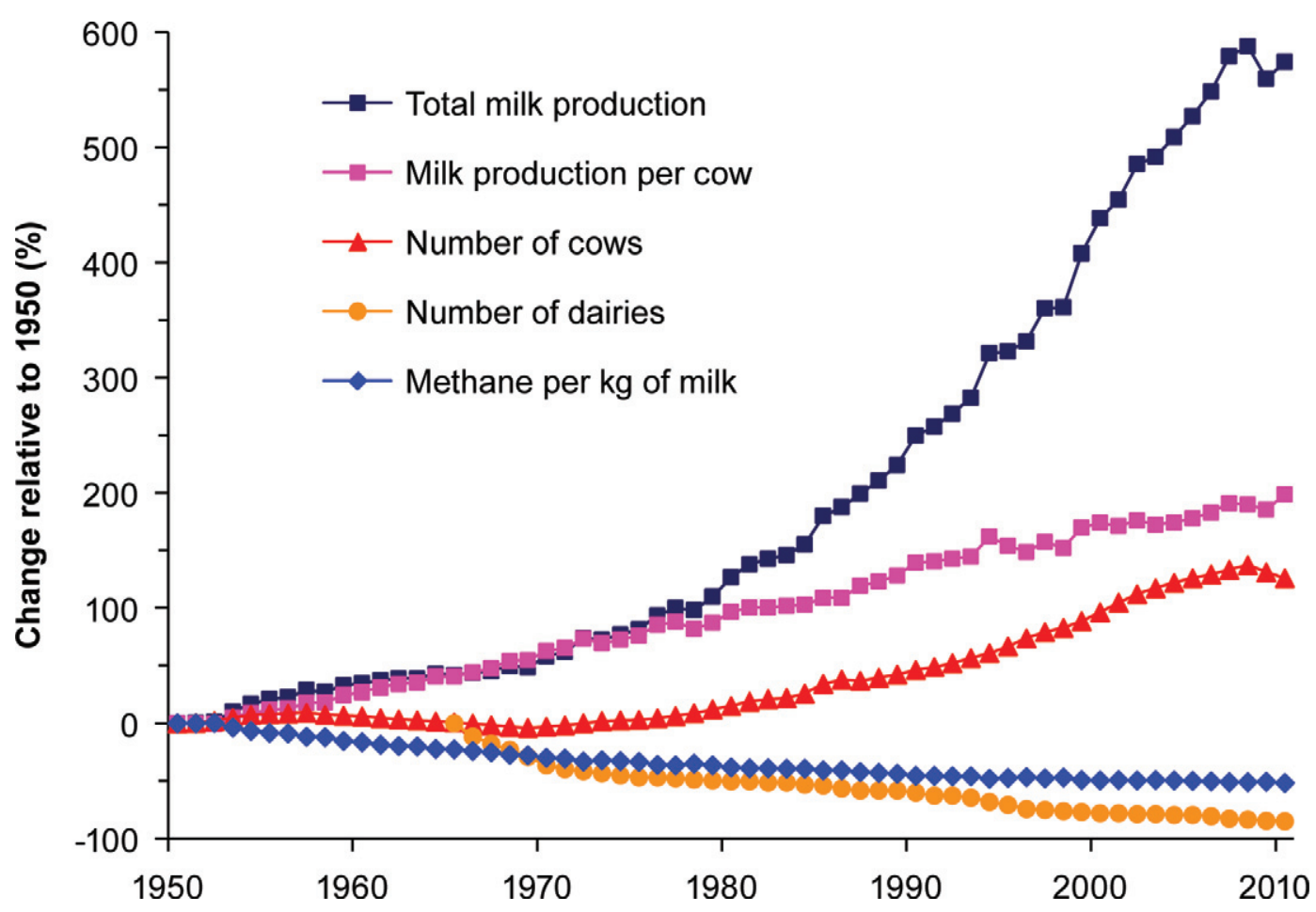

Figure 6. Changes (percentage change relative to 1950) in total milk produced, milk production per cow, total number of dairy cows and dairies, and methane produced per kilogram of milk in the California dairy industry between 1950 and 2010 (updated and modified from Medrano, 2012). Color version available in the online PDF.

Haar and St-Pierre, 2006), but this strategy increases $\mathrm{N}$ excretion (St-Pierre and Thraen, 1999) and, thus, may hinder efforts toward future sustainability. Given the large variation in GHG emissions observed across farms per kilogram of milk produced, it is likely that mitigation strategies will need to be tailored, in part, to the actual situation on each individual farm (Vellinga et al., 2011).

Some authors argue that emissions should be expressed per unit of product (emission intensity) instead of on a per-animal basis (Capper and Cady, 2012). For example, these latter authors suggested that Jersey cows produced $20 \%$ less GHG per unit of cheese compared with Holstein cows. In California, when analyzed on a per-product basis, $\mathrm{CH}_{4}$ emissions decreased $52 \%$ compared with those in 1950 (Figure 6). This reflects the $200 \%$ increase in milk production since that time, with increased cow numbers in the state of just over $100 \%$. However, this logic ignores that greater production efficiencies also result in lower costs (as reviewed above), ultimately driving higher levels of production. From this perspective, increasingly cheap US milk is resulting in increased exports (displacing other foods in foreign markets), resulting in increased environmental costs that are largely borne at the local level.

\section{ECONOMIC ASPECTS}

For any business, a primary economic key driver is the demand for its products and the resulting price from sales. For the US dairy farmer, this driver is the meat, milk, and manufactured dairy products ultimately purchased by consumers. Not surprisingly, milk price was the greatest factor related to variation in dairy farm revenue (Wolf et al., 2009). Prior to the mid-2000s, milk production in the United States was largely determined by domestic market demand. Although some import and export of select dairy products existed, this portion of the industry used only about 2 to $4 \%$ of US milk production. By the mid-2000s, decreased production subsidies in the EU and growing demand from countries such as China resulted in increases in world prices, improving export opportunities for the United States (Nicholson and Stephenson, 2012).

In the United States, the proportion of domestic income spent on food has decreased for many years. Between 1970 and 2010, the percentage of disposable income spent on all food decreased from 13.9 to $9.4 \%$, on average (USDA-ERS, 2011). As Appleby et al. (2003) explained, the continued push to provide cheap food is a problem, in part, because the low costs re- 
flect an inability to properly account for values such as biodiversity, animal welfare, and air and water quality. Costs associated with the maintenance of the cows (e.g., housing, nutrition, and veterinary care) usually have a direct effect on milk price because a sustained gap between direct costs of production and milk price drives farms out of business. On the other hand, more complex costs such as the impact of $\mathrm{N}$ or $\mathrm{P}$ losses into the environment or the impact of overcrowding (to gain greater economies of scale) on animal welfare are almost never factored into the sale price of milk. To command a value in the final market, such costs must usually be regulated and borne by all producers. Otherwise, some producers can become free riders, avoiding the expense of adopting more socially accepted practices, while still benefiting from the price premium associated with the social good of interest.

Preventing free riders from participating in the dairy industry will be required if the sustainability of the US dairy industry is to be a priority. Verification via third party (independent) audits that are science based, transparent, and supported via science-based regulations will no doubt also play an important role. Whether or not incentive programs (monetary or otherwise) that encourage producers to participate will play a significant role on the value (perceived or real) by the producers remains to be seen.

\section{Globalization}

Globalization of the milk market is having a major role in shaping the US dairy industry. The globalization of the food system has occurred in large part as a consequence of refrigeration, cheaper transport, increased communication, and reduced trade barriers and tariffs on agricultural products (Anderson, 2010; Godfray et al., 2010b). The globalization of milk markets results in almost equal milk prices across countries, with the exception of countries that use quotas (Dairy Australia, 2011). Although total costs of production across exporting countries tend to be similar (or they would be unable to compete), the structure of costs varies. For example, pasture-based systems in Australia and New Zealand have relatively high fixed costs associated with purchase price of land, which has increased approximately 7 -fold over the last $20 \mathrm{yr}$ (New Zealand Dairy Statistics; see http://www.dairynz. co.nz/page/pageid/2145866855/New_Zealand_Dairy_ Statistics), but variable costs of production are relatively low because little supplemental feed, housing, and labor are used. In contrast, US dairy producers expect greater levels of cow productivity, but also have greater variable costs due to these additional inputs (IFCN, 2011). The implication of the difference in cost structure between these 2 global regions is that the United States can respond much more rapidly to high world milk prices with increased production, but they also must be sensitive to global supply-demand balance when milk is in oversupply. The US farm milk prices tend to be slightly greater than those in Australia and New Zealand when world markets are tight and slightly less when world markets are flush with milk (Dairy Australia, 2011). An immediate criticism will no doubt be that any movement toward a lower variable cost structure on US dairy farms will come at the expense of productivity (i.e., less rapid growth in milk production per cow), which is at odds with previous proposed solutions (e.g., Capper et al., 2009). However, failure to consider all 3 pillars of sustainability is, in our opinion, shortsighted.

The ability of US dairy industry to respond rapidly to upswings in the world price creates opportunity for export, but may hinder sustainability if increases in milk production at the farm level are promoted in isolation of all factors affecting sustainability in the long term. To date, little consideration has been given to the consequences of global price swings in terms of the social and environmental pillars of sustainability. This type of research is not easy, given the complexity and interrelatedness of the issues affecting sustainability. It will take a concerted inter- and multidisciplinary effort to understand the impact of a fluctuating world milk price on sustainability of the US dairy industry. For instance, the role of economists in this type of research is relatively easy to envision but the recognition that social and natural scientists must play an equally important role in this type of research is less obvious. Lastly, funding for this type of research will be needed, but to date, to our knowledge no funding programs are directed to this type of study.

\section{Scientific and Technological Innovation and Advances}

New technologies are aimed at improving efficiencies of production and reducing costs (Capper et al., 2008). Some of these technologies, such as improved corn or alfalfa varieties, are scale neutral and can be adopted by farms of any size. Other technologies are not scale neutral and require a larger herd size to be economically feasible. One of the best examples of a non-scale neutral technology in the dairy industry is the adoption of the bulk tank and pipeline or milking parlor in the 1950 s and 1960s. Small farms were unable to justify this large single investment, whereas farms with 100 cows or more could afford the capital investment and enjoy the labor savings (Manchester, 1983). 
Genetic gains (Shook, 2006), adoption of management practices such as recombinant bovine somatotropin (rbST; Gulay et al., 2004) and increased milking frequency (Stelwagen, 2001) have all contributed to increases in the productivity of US dairy cows. Many herds today average more than $12,000 \mathrm{~kg} /$ cow per year and the highest-producing cow in the United States has produced more than $34,000 \mathrm{~kg}$ in $1 \mathrm{yr}$ (http://holsteinworld.com/story.php?id = 1124). However, increased production is associated directly or indirectly with increased rates of certain health problems, including mastitis and lameness (Rauw et al., 1998). Most notable has been the decline in fertility in high-producing herds, although high milk production and reproductive performance are not mutually exclusive. This decline in fertility has likely supported, in part, the drive for research and development of new reproductive technologies that are now widely applied in the industry (reviewed by Moore and Thacker, 2006).

Often unclear is whether specific technologies will hinder or improve sustainability. The potential improvements in profitability as a consequence of technologies that improve production or efficiency are easily calculated. However, the acceptability to the public of milk products arising from the introduction of new technologies is more difficult to assess. Insights into future challenges can be gained by looking at the discussion on genetic modification of food products in the EU (Shaw, 2002). Despite the introduction of rigorous science-based risk assessments, this discussion has become highly polarized and politicized (Godfray et al., 2010b). The US dairy industry currently relies heavily on the use of exogenous hormones to mitigate challenges associated with low fertility (Moore and Thacker, 2006); we speculate that few consumers are aware of this practice, and that consumers would likely see this type of technological fix as unnatural (Boogaard et al., 2011) and unwelcome, given their attitudes about food safety (Vanhonacker et al., 2010). Contamination of freshwater sources by these hormones may become a special source of concern in the future. Clearly, research efforts focusing on alternative strategies that are potentially less contentious must begin now.

The public frequently distrusts the use of biotechnology in food production (Gaskell et al., 2000; Lassen et al., 2006), even though it seems clear that biotechnologies, such as the use of transgenics for improving milk production and composition, could play a significant role in ensuring global food security (Wheeler, 2007). Scientists and industry specialists often argue that the public's rejection of biotechnology is due to a lack of understanding of science and that this knowledge deficit can be overcome by educating the public (Lusk and Norwood, 2011; Ahteensuu, 2012). However, solutions that are out of step with societal values may not gain acceptance. In fact, failure to consider public acceptability before and after research and development of certain technologies increases the risk of eroding the generally positive image of the dairy industry in the eyes of today's consumers (Godfray et al., 2010b). We see more work needed in risk analyses, including significant public dialog and consultation (Castle et al., 2005), before investing resources in contentious technologies.

\section{SOCIETAL ASPECTS}

We have left the social aspects of sustainability to the end of our discussion. Our reason for doing so is to emphasize that broad stakeholder input is required if we are to set future directions and goals for research, policy, and producer innovation that will aid us toward a socially sustainable dairy (Swanson et al., 2011).

\section{The Consumer and the Citizen}

The values of consumers can affect directly farm and milk-processing practices if consumers choose to vote with their wallet by refusing to buy certain products that are produced in ways that they do not approve. More generally, citizens who oppose certain practices can provide their political support to new regulations. Both approaches remove control from the producer, perhaps explaining why the dairy industry has tended to either avoid interacting with the public on contentious issues (perhaps hoping that the issue will pass) or has relied on an expert-knows-best mentality, focused on disseminating information to educate the public on industry perspectives to these practices (Driessen, 2012). Consumer attitude surveys indicate that food safety is the highest priority when deciding what to purchase (Vanhonacker et al., 2010; Ingenbleek and Immink 2011). However, consumer-purchasing behavior indicates that point-of-sale price is their highest priority (Harvey and Hubbard, 2013), suggesting a tradeoff between price and attributes. Dagevos and Sterrenberg (2003) state that relationships between consumer attitudes and purchasing behavior are complex and may be best understood by distinguishing between the individual's role as consumer and as citizen. The citizen is the role we play when participating in attitude surveys. The survey-taking persona is rarely in a position, when buying food, to consider all factors needed to make a rational and fully informed, socially responsible decision (Ingenbleek and Immink, 2011). Further evidence of this disconnect between the response of the same person in surveys compared with in-store purchasing information is provided by Hoogland et al. (2007), who argue that consumers rarely understand and value on- 
package labeling describing food production standards, even when the label information was in line with their personal values. Despite these initial reservations, labeling of products in the EU appears to be gaining traction (Gracia et al., 2011), but time will tell whether they become an integral factor for the majority of US consumers.

Appleby et al. (2003) argue that it is inappropriate to put responsibility for social and environmental decisions on customers at the point of sale because that is a time when they have other priorities to juggle and are influenced by viewing others buying cheaper products. It could be argued, therefore, that providing social and environmental choice at the point of sale may hinder the move toward a more sustainable dairy industry. A potential solution would be for overall farm incomes to increase to help pay for some of the required changes needed to allow the entire dairy cattle industry to move toward greater sustainability. Clearly, challenges exist, including finding ways of ensuring that a greater proportion of the retail price finds its way to the producer. This, however, does not solve the free rider problem referred to above. Individual producers could benefit from the increased milk price but still reduce their individual costs by using unsustainable practices. A consistent regulatory framework will be required that prevents individuals from making decisions that benefit themselves at a cost to the larger industry and society.

Another factor potentially contributing to the dilemma is the tremendous food wastage of expired food products, including milk products, that occurs within private US homes and restaurants each day (Hall et al., 2009). This problem is likely exacerbated in part due to the cheap price of milk, which makes it easy for consumers to just buy another carton of milk.

\section{Undocumented Workers}

The current operational structure of most dairy farms in the United States is labor intensive. Some argue that a great need exists to integrate social justice and farm labor rights into the agriculture industry to bring about a greater degree of professionalism (Fraser, 2008; Wolf, 2008) and make the dairy industry a more desirable work place. Presently, the majority of jobs within the US dairy industry are filled with immigrant labor, many of whom are undocumented (Martin, 2002). The dependence on an immigrant labor force (documented or undocumented) on many farms can lead to pressures on community support systems, in part because many experience language barriers. The sustainability of an undocumented labor force is also challenged by attempts in some states to introduce legislation that allows law enforcement officials the right to request documentation from individuals that they suspect are in the country illegally (e.g., Arizona House Bill 2162). If these sorts of legislative changes are upheld, dairy producers will need to find innovative solutions or face the risk of business failure due to increased costs or unavailability of labor. A 2009 National Milk Producers Federation study estimated that eliminating undocumented laborers would reduce the US dairy herd by 1.34 million head, reduce milk production by 11.8 billion $\mathrm{kg} / \mathrm{yr}$, and result in 4,532 dairy farms going out of business (Rosson et al., 2009). This issue can be perceived as a purely practical one as we have framed above. However, we also urge the reader to consider the social sustainability of an industry that persists in using labor practices that are deemed illegal by our broader society.

Work by Bewley et al. (2001) reported that lack of human resource management skills was a major factor inhibiting the growth of Wisconsin dairy farms, indicating that education in terms of human resources management must become a priority. A lack of human resource management skills, combined with the failure to identify solutions regarding the undocumented worker situation in the United States, has left the industry vulnerable. We view this as one of the greatest immediate threats to the sustainability of the dairy industry and we see great need for education and training in alleviating this dire situation. Providing workers and farm managers with educational opportunities that enable them to take pride in their jobs and possibly allow them to work toward elevated responsibilities and career opportunities (and increased salaries) and status within the workings of the dairy farm would be one positive step. This professionalism also may make the dairy industry a more desirable place to work.

\section{Animal Welfare}

Few working in the dairy industry today would disagree with the fact that disease, injury, poor growth rates, and reproductive problems are bad for the animal and also for the viability of the farm. However, only focusing on animal functioning is not sufficient; animal welfare goes beyond health and includes concerns about naturalness (e.g., access to pasture) and affective states of animals (e.g., pain; Fraser et al., 1997).

It is not surprising that the care of animals in US food animal industries is under increased scrutiny, given the changes that have taken place in the EU over the previous 2 decades, where the welfare of agricultural animals on farms, during transport, and at slaughter is highly regulated (Mench et al., 2011). In contrast, the United States currently has only minimal federal regulation for food production animals, as the care of these animals 
falls primarily under state jurisdiction (see Mench et al., 2011 for description of the existing US regulations), but changes are now taking place in some US states. California's 2008 ballot initiative Proposition 2 passed with $63.4 \%$ affirmative vote and was enacted as California's Prevention of Farm Animal Cruelty Act. This act of legislation, which takes effect January 1, 2015, will prohibit the confinement of veal calves, laying hens, and swine for the majority of every day in a manner that does not allow them to turn around freely, lie down, stand up, and fully extend their limbs. Most affected are laying hens currently housed in battery cages. We note that the public supported Proposition 2, despite opponents of this proposition emphasizing that conventional cage housing was developed to promote bird health, egg quality, and lower prices.

Within the dairy industry, we often assume that good animal welfare will result in high-producing cows and, thus, feel that welfare of our herds must be good because production levels are so high. In reality, milk production is a poor indicator of welfare. Clinically ill cows may produce less milk (e.g., Huzzey et al., 2007), but much variation in milk yield is unrelated to welfare. Milk yield is affected by nutritional, genetic, and environmental factors that are welfare neutral, and high levels of production increase the risk of certain welfare problems (von Keyserlingk et al., 2009). Last, research and application efforts where sustainability is the desired outcome also may need to accept that, in some cases, less milk production per cow may be desirable and necessary.

Important welfare concerns include the high prevalence of lameness, calf-feeding practices, the fate of bull calves, pain mitigation during disbudding or dehorning, cow-calf separation, and restrictive housing (e.g., individual calf pens and tie-stall housing; Vanhonacker et al., 2009; von Keyserlingk et al., 2009). A growing body of evidence also exists that society places considerable value on cattle having access to the outdoors (i.e., pasture), where they have fresh air and freedom to roam naturally (Ellis et al., 2009; Boogaard et al., 2011).

The past decade has seen the emergence of several very successful streams of research addressing practical problems in the care and housing of dairy cattle, but practice on farms is sometimes slow to adjust to or adopt findings of this research. For example, tail docking continues on many farms despite more than a decade of research showing that tail docking harms cows while providing none of the hoped for or presumed benefits in cow cleanliness and cow health (Sutherland and Tucker, 2011). The public and many within the dairy industry also see docking as needlessly harmful (Weary et al., 2011). The combination of public concern and lack of scientific support has made the practice of tail docking an obvious target for animal advocates and legislative bans. California was the first state to ban this practice (Senate Bill 135, Section 597n), effective January 1, 2010, followed by Rhode Island in 2012 (Senate Bill 458). The state of Ohio has implemented a phase-out period for tail docking through their government-run Livestock Care Standards Board that forms the Rules; effective January 1, 2018, tail docking will be banned (http:// www.agri.ohio.gov/LivestockCareStandards/docs/ OLCS\%20Bovine\%20-\%20Final.pdf).

We suggest that rapid adoption of scientifically established best practices (such as no tail docking and pain control for disbudding) provide a key area of opportunity for the dairy industry. The current polarization of values regarding the care of farm animals in the United States has, and likely will continue, to force the legislative system to intervene, especially if the broader dairy industry fails to take action in those areas where the scientific evidence is clear.

More work is needed to help producers implement changes that improve welfare, but little is known about how best to encourage and effectively facilitate such changes. One promising approach is the use of benchmarking methods that provide farmers with data that they can use to better evaluate their performance relative to their peers (von Keyserlingk et al., 2012).

\section{Public Engagement}

Diverse methodologies are available for public engagement (e.g., Secko et al., 2008; Avard et al., 2009; Swanson et al., 2011) and we strongly encourage the use of these approaches. It is important to note that public acceptability is not limited to the social pillar of sustainability. Many of the concerns about the economics and the environmental impacts of food production are rooted in public acceptability (Blandford and Fulponi, 1999); an understanding of public values is, thus, important for all aspects of sustainable dairy production (Tucker et al., 2013).

Although we may avoid some controversy in the short term by keeping the public unaware of common practices, a lack of sustained engagement provides no feedback mechanism to ensure that any changes in practice are in harmony with public expectations. For instance, engagement between the egg industry, the public, and the humane movement allowed this industry to move in an orderly fashion away from the use of battery cages; the United Egg Producers, in cooperation with the Humane Society of the United States, recently pledged that they will work together to discontinue the use of the conventional battery cages to better align poultry housing methods with public values (http://www.unitedegg. org/homeNews/UEP_Press_Release_7-7-11.pdf). The 
benefit to egg producers of this kind of industry-wide engagement, collaboration, and agreement is that the cost of this change will be borne by all producers and, thus, incorporated into the price of the product to consumers. We encourage similar engagement between the dairy industry and other stakeholders to begin a more collaborative approach to addressing shared welfare concerns to foster long-term sustainability.

\section{Multidisciplinary Research- The Road to Sustainability}

To date, the majority of public and private agricultural research in the United States has been focused on productivity and efficiency, particularly on technologies that complement existing production systems and lead to benefits for the private sector (NRC, 2010). This approach alone will not address the gaps in knowledge and educational needs described above for many aspects of the sustainability of dairy production and consumer understanding. We also require transformative research that allows for whole system redesign (Reganold et al., 2011). The challenge is that transformational research will doubtlessly require strong public funding, as this type of research is less likely to yield immediate company or shareholder profits (the primary driver behind private sector research). Much of the public funding currently devoted to agricultural research in the United States is focused on production and efficiency (Reganold et al., 2011); shifting resources to fund new transdisciplinary research is desperately needed. This research must address the complex socio-ecological factors affecting the sustainability of the dairy industry.

\section{LIMITATIONS TO OUR REVIEW}

There are numerous limitations to our review. Sustainability is in itself a complex issue with diverse factors. For instance, some issues presented herein as opportunities may be argued equally by other stakeholders to be threats. Another limitation is that our discussions did not include input from key stakeholders, including producers, retailers, consumers, and the general public. We strongly encourage future work to identify and bring together a broader assembly of stakeholders. Hopefully, this review can help set the framework for the needed dialog and action forward. In particular, we see benefits to engaging animal advocates and environmental protectionists in these types of discussions. Critics of animal agriculture may benefit from listening to the voices of the dairy industry just as those of us from within the industry can learn by listening to our critics.

\section{CONCLUSIONS AND FINAL THOUGHTS}

We have identified and presented several major factors affecting the future sustainability of the US dairy industry, including climate change, rapid scientific and technological innovation and advances, globalization, failure to integrate societal values, and lack of multidisciplinary research initiatives. We also argued that sustainability is more than economic profitability; it also relates to environmental and societal concerns, including the quality of life of workers and the animals in dairy farms. Public input regarding the acceptability of practices, including new technologies, is required. Sustained engagement between and among producers, various sectors of the industry (e.g., processors and producers), consumers, and citizens will be essential to recognize and implement more sustainable practices. We recognize that this will require a major paradigm shift on the part of the US dairy industry to collaboratively develop a path to ensure the long-term sustainability of the industry.

Clearly, much work remains to be done, particularly in identifying mechanisms that enable US dairy producers to voice their concerns independent of other sectors of the industry that may have competing demands or agendas. An example of this exists just north of the US border. The Dairy Farmers of Canada (DFC) is an organization run by producers for producers, with elected producer representatives from each of the provinces. This organization provides leadership in funding research; DFC commits approximately $\$ 750,000$ per year to production research (pre-farm gate) and typically leverages this investment by demanding that applicants seek matching funds. This commitment to research has resulted in a large body of published literature that provided much of the science cited in the recently published Code of Practice for the Care and Handling of Dairy Cattle. This science-based document describes best practices agreed upon by diverse stakeholder groups, including the dairy industry, government, grocery chain distributors, and the Canadian Federation of Humane Societies (see NFACC, 2009).

In contrast, a significant portion of the agricultural research undertaken by US research institutions is sponsored by corporations and, as such, is typically focused on measures of immediate economic interest typically hinging on increased animal or farm productivity and efficiency. Although check-off dollars from milk sales from US dairy farmers are collected by Dairy Management Inc. (Rosemont, Illinois), these funds are used for demand-related research and marketing and not for dairy production practices research. This leaves an important gap in the funding of research that addresses the growing public concerns about dairy cattle 
production, including sustainability, environmental impact, and the welfare of food-production animals. We strongly encourage more public funding sources (including by the USDA), and the dairy industry at large, to begin funding the research (including that which falls into the domain of social science) that will be required to support improved sustainable practices in the years to come.

Engagement means more than advertisement of an entrenched position; it will involve conversations in which the various sectors of the dairy industry carefully listen to, and dialog with, the citizens in the broader society. It means that the dairy industry must be prepared to make changes to accommodate public expectations. This approach will benefit the longerterm sustainability of the industry by helping to ensure that consumers (and citizens) have confidence in dairy production methods and that the practices of dairy farmers fit well within the values of our broader society. Moving toward sustainability will require courage to step beyond expected roles, with the understanding that working together is the most practical way forward. We recognize that this will not be easy, but if participants come to the table with a spirit of respect, compromise, and tolerance, then there is hope that practical solutions can be identified.

We hope that our review will encourage system-wide strategic planning, the needed associated research, and actions required to create a sustainable dairy system that is environmentally sound, socially acceptable, and economically viable. Our review is based on the view that continued research in this area is essential.

\section{ACKNOWLEDGMENTS}

We thank the 3 anonymous reviewers for their insightful comments that greatly improved this review. Robert Roberts (Penn State University, University Park, PA), Peter Krawczel (University of Tennessee, Knoxville), Erin Fitzgerald and Juan Tricarico (Dairy Innovation Center, Rosemont, IL), and Roger Cady (Elanco Animal Health, Greenfield, IL) are thanked for their contributions to our discussions at various stages of this exercise. We thank Julie Huzzey (University of British Columbia, Vancouver, BC, Canada) for her help with Figure 2. M. A. G. von Keyserlingk thanks her colleagues in the Animal Welfare Program (University of British Columbia), particularly Dan Weary and David Fraser, for the numerous discussions over the last decade that helped shape many of the arguments presented in this paper. E. Kebreab thanks the Sesnon Endowed Chair program (University of California-Davis) for providing funds to participate in the meetings and discussions. We also thank the William H. Miner
Agricultural Research Institute (Chazy, NY), Elanco Animal Health, and the Dairy Innovation Center for providing the meeting places that allowed this group to meet face to face.

\section{REFERENCES}

Ahteensuu, M. 2012. Assumptions of the deficit model type of thinking: Ignorance, attitudes, and science communication in the debate on genetic engineering in agriculture. J. Agric. Environ. Ethics $25: 295-313$.

Alvarado, C. S., S. G. Gibbs, A. Gandara, C. Flores, W. W. Hurd, and C. F. Green. 2012. The potential for community exposures to pathogens from an urban dairy. J. Environ. Health 74:22-28.

ASAE (American Society of Agricultural Engineers). 2005. Manure production and characteristics. ASAE Standard D384.2. Am. Soc. Agric. Eng., St. Joseph, MI.

Anderson, K. 2010. Globalization's effects on world agricultural trade, 1960-2050. Phil. Trans. R. Soc. Lond. B Biol. Sci. 365:3007-3021.

Appleby, M. C., N. Cutler, J. Gazzard, P. Goddard, J. A. Milne, C. Morgan, and A. Redfern. 2003. What price cheap food? J. Agric. Environ. Ethics 16:395-408.

Atandi, E., and S. Rahman. 2012. Prospect of anaerobic co-digestion of dairy manure: A review. Environ. Technol. Rev. 1:127-135. http://dx.doi.org/10.1080/09593330.2012.698654.

Avard, D., L. M. Bucci, M. M. Burgess, J. Kaye, C. Heeney, Y. Farmer, and A. Cambon-Thomsen. 2009. Public health genomics (PHG) and public participation: Points to consider. J. Public Deliberation 5:7.

Bargo, F., L. D. Muller, E. S. Kolver, and J. E. Delahoy. 2003. Invited review: Production and digestion of supplemented dairy cows on pasture. J. Dairy Sci. 86:1-42.

Battisti, D. S., and R. L. Naylor. 2009. Historical warnings of future food insecurity with unprecedented seasonal heat. Science $323: 240-244$.

Bewley, J., R. W. Palmer, and D. B. Jackson-Smith. 2001. An overview of experiences of Wisconsin dairy farmers who modernized their operations. J. Dairy Sci. 84:717-729.

Blandford, D., and L. Fulponi. 1999. Emerging public concerns in agriculture: Domestic policies and international trade commitments. Eur. Rev. Agric. Econ. 26:409-424.

Blayney, D. 2002. The changing landscape of U.S. milk production. USDA Statistical Bulletin No. SB-978. US Department of Agriculture Economic Research Service, Washington, DC.

Boadi, D. A., C. Benchaar, J. Chiquette, and D. Massé. 2004. Mitigation strategies to reduce enteric methane emissions from dairy cows: Update review. Can. J. Anim. Sci. 84:319-336.

Boogaard, B. K., B. B. Bock, S. J. Oosting, J. S. C. Wiskerke, and A. J. van der Zijpp. 2011. Social acceptance of dairy farming: The ambivalence between the two faces of modernity. J. Agric. Environ. Ethics 24:259-282.

Capper, J. L., and R. A. Cady. 2012. A comparison of the environmental impact of Jersey compared with Holstein milk for cheese production. J. Dairy Sci. 95:165-176.

Capper, J. L., R. A. Cady, and D. E. Bauman. 2009. The environmental impact of dairy production: 1944 compared with 2007. J. Anim. Sci. 87:2160-2167.

Capper, J. L., E. Castañeda-Gutiérrez, R. A. Cady, and D. E. Bauman. 2008. The environmental impact of recombinant bovine somatotropin (rbST) use in dairy production. Proc. Natl. Acad. Sci. USA 105:9668-9673.

Castle, D., K. Finlay, and S. Clark. 2005. Proactive consumer consultation: The effect of information provision on response to transgenic animals. J. Public Affairs 5:200-216.

Cochrane, W. 1958. Farm Prices: Myth and Reality. North Central Publishing Co. St. Paul, MN.

CAST (Council for Agricultural Science and Technology). 2012. Water and land issues associated with animal agriculture: U.S. perspective. CAST Issue Paper IP50. CAST, Ames, IA. 
Croney, C. C., and R. Anthony. 2011. Invited review: Ruminating conscientiously: Scientific and socio-ethical challenges for US dairy production. J. Dairy Sci. 94:539-546.

Dagevos, H., and L. Sterrenberg. 2003. Burgers en Consumenten: Tussen tweedeling en twee-eenheid. [Title translation: Citizens and Consumers: Between Dichotomy and Duality Rule]. Wageningen Academic Publishers, Wageningen, the Netherlands.

Dairy Australia. 2011. Australian Dairy Industry in Focus 2011. Accessed Dec. 18, 2012. http://dairy.wisc.edu/PubPod/Reference/ Library/DA_Infocus_2011.pdf.

Das, S. M., I. Redbo, and H. Wiktorsson. 2001. Behaviour of Zebu and crossbred cows in restricted suckling groups. Appl. Anim. Behav. Sci. $72: 263-270$.

Driessen, C. 2012. Farmers engaged in deliberative practices; an ethnographic exploration of the mosaic of concerns in livestock agriculture. J. Agric. Environ. Ethics 25:163-179.

Ellis, K. A., K. Billington, B. McNeil, and D. E. F. McKeegan. 2009 Public opinion on UK milk marketing and dairy cow welfare. Anim. Welf. 18:267-282.

Environmental Science Associates. 2011. Economic Feasibility of Dairy Manure Digester and Co-Digester Facilities in the Central Valley of California. Accessed July 5, 2012. http://www.swrcb.ca.gov/ rwqcb5/water_issues/dairies/dairy_program_regs_requirements/ final_dairy_digstr_econ_rpt.pdf.

EWG (Environmental Working Group). 2012. Farm Subsidy Database. Accessed Feb. 3, 2012. http://farm.ewg.org/index.php.

Falk, A. C., D. M. Weary, C. Winkler, and M. A. G. von Keyserlingk. 2012. Preference for pasture versus freestall housing by dairy cattle when stall availability indoors is reduced. J. Dairy Sci. 95:6409-6415.

FAO (Food and Agriculture Organization of the United Nations). 2010. Main findings and short- and medium-term recommendations. FAO, Rome. Accessed Feb. 6, 2012. http://www.fao.org/nr/ water/news/clim-change.html.

Fraser, D. 2008. Animal welfare and the intensification of animal production. Pages 167-189 in The Ethics of Intensification. P. B. Thompson, ed. Springer Science + Business Media B.V., Dordrecht, the Netherlands.

Fraser, D., D. M. Weary, E. A. Pajor, and B. N. Milligan. 1997. A scientific conception of animal welfare that reflects ethical concerns. Anim. Welf. 6:187-205.

Gaskell, G., N. Allum, M. Bauer, J. Durant, A. Allansdottir, H. Bonfadelli, D. Boy, S. de Cheveigné, B. Fjaestad, J. M. Gutteling, J. Hampel, E. Jelsøe, J. Correia Jesuino, M. Kohring, N. Kronberger, C. Midden, T. H. Nielsen, A. Przestalski, T. Rusanen, G. Sakellaris, H. Torgersen, T. Twardowski, and W. Wagner. 2000. Biotechnology and the European public. Nat. Biotechnol. 18:935-938.

Godfray, H. C. J., J. R. Beddington, I. R. Crute, L. Haddad, D. Lawrence, J. F. Muir, J. Pretty, S. Robinson, S. M. Thomas, and C. Toulmin. 2010a. Food security: The challenge of feeding 9 billion people. Science 327:812-818.

Godfray, H. C. J., I. R. Crute, L. Haddad, D. Lawrence, J. F. Muir, N. Nisbett, J. Pretty, S. Robinson, C. Toulmin, and R. Whitely. 2010b. The future of the global food system. Philos. Trans. R Soc. Lond. B Biol. Sci. 365:2769-2777.

Gracia, A., M. L. Loureiro, and R. M. Nayga Jr. 2011. Valuing an EU animal welfare label using experimental auctions. Agric. Econ. 42:669-677.

Grout, A. S., D. M. Veira, D. M. Weary, M. A. G. von Keyserlingk, and D. Fraser. 2006. Differential effects of sodium and magnesium sulfate on water consumption by beef cattle. J. Anim. Sci. 84:1252-1258.

Gulay, M. S., M. J. Hayen, M. Liboni, T. I. Belloso, C. J. Wilcox, and H. H. Head. 2004. Low doses of bovine somatotropin during the transition period and early lactation improves milk yield, efficiency of production, and other physiological responses of Holstein cows. J. Dairy Sci. 87:948-960.

Hagemann, M., T. Hemme, A. Ndambi, O. Alqaisi, and M. N. Sultana. 2011. Benchmarking of greenhouse gas emissions of bovine milk production systems for 38 countries. Anim. Sci. Feed Technol. 166-167:46-58.
Hall, K. D., J. Guo, M. Dore, and C. C. Chow. 2009. The progressive increase of food waste in America and its environmental impact. PLoS ONE 4:e7940.

Harter, T., J. R. Lund, J. Darby, G. E. Fogg, R. Howitt, K. K. Jessoe, G. S. Pettygrove, J. F. Quinn, J. H. Viers, D. B. Boyle, H E. Canada, N. DeLaMora, K. N. Dzurella, A. Fryjoff-Hung, A. D. Hollander, K. L. Honeycutt, M. W. Jenkins, V. B. Jensen, A. M. King, G. Kourakos, D. Liptzin, E. M. Lopez, M. M. Mayzelle, A. McNally, J. Medellin-Azuara, and T. S. Rosenstock. 2012. Addressing Nitrate in California's Drinking Water with a Focus on Tulare Lake Basin and Salinas Valley Groundwater. Report for the State Water Resources Control Board Report to the Legislature. Center for Watershed Sciences, University of California, Davis. Accessed Aug. 6, 2012. http://groundwaternitrate.ucdavis.edu.

Harvey, D., and C. Hubbard. 2013. Reconsidering the political economy of farm animal welfare: An anatomy of market failure. Food Policy 38:105-114

Hoekstra, A. Y. 2012. The hidden water resource use behind meat and dairy. Anim. Front. 2:3-8.

Hoogland, C. T. J. de Boer, and J. J. Boersema. 2007. Food and sustainability: Do consumers recognize, understand and value onpackage information on production standards? Appetite 49:47-57.

Huzzey, J. M., D. M. Veira, D. M. Weary, and M. A. G. von Keyserlingk. 2007. Prepartum behavior and dry matter intake identify dairy cows at risk for metritis. J. Dairy Sci. 90:3220-3233.

IER (Institute for Energy Research). 2011. The Status of Renewable Electricity Mandates in the States. Accessed Aug. 28, 2012. http://www.instituteforenergyresearch.org/wp-content/uploads/2011/01/IER-RPS-Study-Final.pdf.

IFCN (International Farm Comparison Network). 2011. Dairy Report 2011. Comparison of the typical farms 2010: Time series analysis 2000-2010 at farm level. Pages 36-37 in Proc. 12th IFCN Dairy Conf., Kiel, Germany.

Ingenbleek, P. T. M., and V. M. Immink. 2011. Consumer decisionmaking for animal-friendly products: Synthesis and implications. Anim. Welf. 20:11-19.

IPCC (Intergovernmental Panel on Climate Change). 2006. IPCC Guidelines for National Greenhouse Gas Inventories. Prepared by the National Greenhouse Gas Inventories Programme. S. Eggleston, L. Buendia, K. Miwa, T. Ngara, and K. Tanabe, ed. Institute for Global Environmental Strategies (IGES), Hayama, Japan.

IPCC (Intergovernmental Panel on Climate Change). 2007. Summary for policy makers. Page 23. Cambridge Press, Cambridge, UK and New York, NY.

Johnson, K. A. and D. E. Johnson. 1995. Methane emissions from cattle. J. Anim. Sci. 73:2483-2492.

Kaparaju, P., and J. Rintala. 2010. Mitigation of greenhouse gas emissions by adopting anaerobic digestion technology on dairy, sow and pig farms in Finland. Renew. Energy 36:31-41.

Karl, T. R., J. M. Melillo, T. C. Peterson, and S. J. Hassol. 2009 Global climate change impacts in the United States. Cambridge University Press, New York, NY.

Kebreab, E., K. Clark, C. Wagner-Riddle, and J. France. 2006. Methane and nitrous oxide emissions from Canadian animal agriculture: A review. Can. J. Anim. Sci. 86:135-158.

Kellogg, R. L., C. H. Lander, D. C. Moffitt, and N. Gollehon. 2000. Manure nutrients relative to the capacity of cropland and pastureland to assimilate nutrients: Spatial and temporal trends for the United States. USDA-NRCS-ERS Publication No. nps00-0579. US Department of Agriculture Natural Resources Conservation Service (NRCS) and Economic Research Service (ERS), Washington, DC

Kirkhorn, S. R., and V. F. Garry. 2000. Agricultural lung diseases. Environ. Health Perspect. 108:705-712.

Knowlton, K. F., J. S. Radcliffe, D. A. Emmerson, and C. L. Novak. 2004. Animal management to reduce phosphorus losses to the environment. J. Anim. Sci. 82(E. Suppl.):E173-E195.

Kriegel, T. 2012. Comparing feed costs of Wisconsin dairy grazing and California confinement farms from 1998 to 2010. http://cdp. wisc.edu. 
Lassen, J., M. Gjerris, and P. Sandøe. 2006. After Dolly-Ethical limits to the use of biotechnology on farm animals. Theriogenology 65:992-1004

Legrand, A. L., M. A. G. von Keyserlingk, and D. M. Weary. 2009. Preference and usage of pasture versus free-stall housing by lactating dairy cattle. J. Dairy Sci. 92:3651-3658.

Ludington, D. C., A. L. Johnson, J. A. Kowalski, and A. L. Mage. 2004. Dairy Farm Energy Management Guide: California. Southern California Edison, Rosemead, CA.

Lusk, J. L., and F. B. Norwood. 2011. Animal welfare economics. Appl. Econ. Perspect. Pol. 33:463-483.

MacDonald, J. M., E. J. O'Donoghue, W. D. McBride, R. F. Nehring, C. L. Sandretto, and R. Mosheim. 2007. Profits, costs, and the changing structure of dairy farming. Economic Research Service Report Number 47. US Department of Agriculture Economic Research Service (USDA-ERS), Washington, DC.

Manchester, A. 1983. The Public Role in the Dairy Economy. Westview Press, Boulder, CO.

Martin, P. 2002. "Guest Workers: New Solution, New Problem?" A study conducted for the Pew Hispanic Center, Washington, DC. Accessed Aug. 31, 2012. http://www.pewhispanic.org/files/ reports $/ 7$.pdf.

Martin, W., and D. Mitra. 2001. Productivity growth and convergence in agriculture and manufacturing. Econ. Dev. Cult. Change 49:403-423.

Medrano, J. F. 2012. Genetic sustainability and biodiversity: Challenges to the California dairy industry. Pages 549-561 in Biodiversity in Agriculture: Domestication, Evolution and Sustainability. P. Gepts, T. R. Famula, R. L. Bettinger, S. B. Brush, A. B. Damania, P. E. McGuire, and C.O. Qualset, ed. Cambridge University, Press, Cambridge, UK.

Mekonnen, M. F., and A. Y. Hoekstra. 2012. A global assessment of the water footprint of farm animal product. Ecosystems (N.Y.) 15:401-415.

Mench, J. A., D. A. Sumner, and J. T. Rosen-Molina. 2011. Sustainability of egg production in the United States-The policy and market context. Poult. Sci. 90:229-240.

Mergaert, K., and W. Verstraete. 1987. Microbial parameters and their control in anaerobic digestion. Microbiol. Sci. 4:348-351.

Meul, M., S. Van Passel, D. Fremaut, and G. Haesaert. 2012. Higher sustainability performance of intensive grazing verses zero-grazing dairy systems. Agron. Sustain. Dev. 32:629-638.

Milani, F. X., D. Nutter, and G. Thoma. 2011. Invited review: Environmental impacts of dairy processing and products. J. Dairy Sci. 94:4243-4254.

Moore, K., and W. W. Thacker. 2006. Major advances associated with reproduction in dairy cattle. J. Dairy Sci. 89:1254-1266.

NAHMS (National Animal Health Monitoring System). 2008. Highlights of Dairy 2007 Part II: Changes in the U.S. dairy cattle industry, 1991-2007. US Department of Agriculture:Animal and Plant Health Inspection Service:Veterinary Services:Centers for Epidemiology and Animal Health (USDA:APHIS:VS:CEAH), Fort Collins, CO.

NFACC (National Farm Animal Care Council). 2009. Code of practice for the care and handling of dairy cattle. Dairy Farmers of Canada and the NFACC, Ottawa, Ontario, Canada.

NMPF (National Milk Producers Federation). 2012. Dairy data highlights. Accessed June 20, 2012. http://www.nmpf.org/dairyproducer-highlights.

NRC. 2003. Air Emissions from Animal Feeding Operations: Current Knowledge, Future Needs. National Academies Press, Washington, DC.

NRC. 2010. Toward sustainable agricultural systems in the 21st century. The National Academies, Washington, DC.

Nicholson, C., and M. Stephenson. 2012. U.S. Dairy Product Exports: Growth Patterns, Causes and Implications. CoBank Knowledge Exchange, Denver, CO.

Nickerson, C., R. Ebel, A. Borchers, and F. Carriazo. 2011. Major Uses of Land in the United States, 2007. Page 57. United States Department of Agriculture Economic Research Service, Washington, DC.
Parker, J. 2011. The 9 billion-people question: A special report on feeding the world. The Economist. February 26. Pages 1-13.

Pimentel, D., A. Marklein, M. A. Toth, M. N. Karpoff, G. S. Paul, R. McCormack, J. Kyriazis, and T. Krueger. 2009. Food versus biofuels: Environmental and economic costs. Hum. Ecol. 37:1-12.

Rauw, W. M., E. Kanis, E. N. Norrdhuizen-Stassen, and F. J. Grommers. 1998. Undesirable side effects of selection for high production efficiency in farm animals: A review. Livest. Prod. Sci. 56:15-33.

Ravagnolo, O., I. Misztal, and G. Hoogenboom. 2000. Genetic component of heat stress in dairy cattle, development of heat index function. J. Dairy Sci. 83:2120-2125.

Reganold, J. P., D. Jackson-Smith, S. S. Batie, R. R. Harwood, J. L. Kornegay, D. Bucks, C. B. Flora, J. C. Hanson, W. A. Jury, D. Meyer, A. Schumacher Jr., H. Sehmsdorf, C. Shennan, L. A. Thrupp, and P. Willis. 2011. Transforming U.S. Agriculture. Science 332:670-671.

Ribaudo, M., N. Gollehon, M. Aillery, J. Kaplan, R. Johansson, J. Agapoff, L. Christensen, V. Breneman, and M. Peters. 2003. Manure management for water quality: Costs to animal feeding operations of applying manure nutrients to land. USDA-ERS Agricultural Economic Report No. AER-824. US Department of Agriculture Economic Research Service (USDA-ERS), Washington, DC.

Rosegrant, M. W., X. Cai, and S. A. Cline. 2002. World water and food to 2025. International Food Policy Research Institute, Washington, DC.

Rosson, P., F. Adcock, D. Susanto, and D. Anderson. 2009. The Economic Impacts of Immigration on U.S. Dairy Farms. National Milk Producers Federation, Arlington, VA.

Sanderson, M. A., D. Wedin, and B. Tracey. 2009. Grassland: Definition, origins, extent, and future. Pages 57-74 in Grassland: Quietness and Strength for a New American Agriculture. W. F. Wedin and S. L. Fales, ed. American Society of Agronomy, Crop Science Society of America, and Soil Science Society of America, Madison, WI

Schade, C., and D. Pimentel. 2010. Population crash: Prospects for famine in the twenty-first century. Environ. Dev. Sustain. 12:245262.

Secko, D. M., M. Burgess, and K. O'Doherty. 2008. Perspectives on engaging the public in the ethics of emerging biotechnologies: From salmon to biobanks to neuroethics. Account. Res. 15:283-302.

Shaw, A. 2002. "It goes against the grain.' Public understandings of genetically modified (GM) food in the UK". Public Understand. Sci. 11:273-291.

Shiklomanov, I. A. 2000. Appraisal and assessment of world water resources. Water Int. 25:11-32.

Shook, G. E. 2006. Major advances in determining appropriate selection goals. J. Dairy Sci. 89:1349-1361.

Smith, P., P. J. Gregory, D. van Vuuren, M. Obersteiner, P. Havlík, M. Rounsevell, J. Woods, E. Stehfest, and J. Bellarby. 2010 Competition for land. Philos. Trans. R. Soc. Lond. B Biol. Sci. 365:2941-2957.

Smith, R. A., and R. B. Alexander. 2000. Sources of nutrients in the nation's watersheds. Pages $13-21$ in Managing Nutrients and Pathogens from Animal Agriculture. Northeast Regional, Camp Hill, PA.

St-Pierre, N. R., and C. S. Thraen. 1999. Animal grouping strategies, sources of variation, and economic factors affecting nutrient balance on dairy farms. J. Anim. Sci. 77:72-83.

Steinfeld, H., P. Gerber, T. Wassenaar, V. Castel, M. Rosales, and C. de Haan. 2006. Livestock's Long Shadow: Environmental Issues and Options. Food and Agriculture Organization of the United Nations (FAO), Rome, Italy.

Stelwagen, K. 2001. Effect of milking frequency on mammary functioning and shape of the lactation curve. J. Dairy Sci. 84(E. Suppl.):E204-E211.

Strzepek, K., and B. Boehlert. 2010. Competition for water for the food system. Philos. Trans. R. Soc. Lond. B Biol. Sci. 365:29272940

Sutherland, M. A., and C. B. Tucker. 2011. The long and short of it: A review of tail docking in farm animals. Appl. Anim. Behav. Sci. 135:179-191. 
Swanson, J. C., Y. Lee, P. B. Thompson, R. Bawden, and J. A. Mench. 2011. Integration: Valuing stakeholder input in setting priorities for socially sustainable egg production. Poult. Sci. 90:2110-2121.

Taheripour, F., T. W. Hertel, and W. E. Tyner. 2011. Implications of biofuels mandates for the global livestock industry: A computable general equilibrium analysis. Agric. Econ. 42:325-342.

Thompson, P. B. 1997. Sustainability as a norm. Phil. and Tech. 2:75-93.

Thompson, P. B. 2007. Agricultural sustainability: What it is and what it is not. Int. J. Agric. Sustain. 5:5-16.

Thornton, P. K. 2010. Livestock production: Recent trends, future prospects. Philos. Trans. R. Soc. Lond. B Biol. Sci. 365:28532867.

Tucker, C. B., J. Mench, and M. A. G. von Keyserlingk. 2013. Animal welfare: An integral component of sustainability. In Sustainable Animal Agriculture. E. Kebreab, ed. CAB International, Wallingford, UK. In press.

United Nations Population Division. 2012. World Urbanization Prospects, the 2011 Revision. Department of Economic and Social Affairs, New York, NY.

US Census Bureau. 2010. 2010 Census urban and rural classification and urban area criteria. US Department of Commerce. Accessed Aug. 28, 2012. http://www.census.gov/geo/www/ ua/2010urbanruralclass.html.

USDA (US Department of Agriculture). 2011. U.S. agriculture and forestry greenhouse gas inventory: 1990-2008. Technical Bulletin No. 1930. Climate Change Program Office, Office of the Chief Economist, Washington, DC.

USDA-EPA (US Department of Agriculture Environmental Protection Agency). 1999. Unified National Strategy for Animal Feeding Operations, March 9, 1999. Accessed Aug. 28, 2012. http://www. epa.gov/npdes/pubs/finafost.pdf.

USDA-ERS (US Department of Agriculture Economic Research Service). 2011. Consumer Price Index, Table 7-Food expenditures by families and individuals as a share of disposable personal income. Accessed July 17, 2012. http://www.ers.usda.gov/datafiles/ Food_Expenditures/Food_Expenditures/2010Table7.xls.

USDA-ERS (US Department of Agriculture Economic Research Service). 2012. Monthly cost of production estimates. USDA-ERS, Washington, DC. Accessed Sep. 23, 2012. http://www.ers.usda. gov/data-products/milk-cost-of-production-estimates.aspx.

USDA-NASS (US Department of Agriculture National Agricultural Statistics Service). 2002. Milk Production. February 2002. Table-Milk production: Percent of production by size group, selected states, and United States, 2000-2001. Accessed Aug. 28, 2012. http://usda01.library.cornell.edu/usda/nass/ MilkProd//2000s/2001/MilkProd-02-16-2001.pdf.

USDA-NASS (US Department of Agriculture National Agricultural Statistics Service). 2009. 2007 Census of Agriculture-United States Data. Pages 178-205. Accessed Aug. 28, 2012. http:// www.agcensus.usda.gov/Publications/2007/Full_Report/Volume_ 1,_Chapter_1_US/st99_1_062_062.pdf.

USDA-NASS (US Department of Agriculture National Agricultural Statistics Service). 2012a. Farms, Land in Farms, and Livestock Operations. Accessed Aug. 28, 2012. http://usda.mannlib.cornell. edu/MannUsda/viewDocumentInfo.do?documentID=1259.

USDA-NASS (US Department of Agriculture National Agricultural Statistics Service). 2012b. Milk Production. August 17, 2012. Table-Milk cows and production by quarter-United States: 2011-2012. Accessed Aug. 28, 2012. http://www.nass.usda.gov/ Publications/Todays_Reports/reports/mkpr0612.pdf.
USDA-OCE (US Department of Agriculture Office of the Chief Economist). 2012. USDA Agricultural Projections to 2021. Page 102. W. A. O. Board, ed. Washington, DC.

US EPA (Environmental Protection Agency). 2012a. Relation between nitrate in water wells and potential sources in the lower Yakima Valley, Washington. Accessed Oct. 22, 2012. http:// www.epa.gov/region10/pdf/sites/yakimagw/nitrate_in_water_ wells_study_9-27-2012.pdf.

US EPA (Environmental Protection Agency). 2012b. Chapter 6: Agriculture in US Greenhouse Gas Inventory. Accessed Aug. 6, 2012. http://www.epa.gov/climatechange/Downloads/ghgemissions/ US-GHG-Inventory-2012-Chapter-6-Agriculture.pdf.

Van Nevel, C. J., and D. I. Demeyer. 1996. Control of rumen methanogenesis. Environ. Monit. Assess. 42:73-97.

VandeHaar, M. J., and N. St-Pierre. 2006. Major advances in nutrition: Relevance to the sustainability of the dairy industry. J. Dairy Sci. 89:1280-1291.

Vanhonacker, F., E. Van Poucke, F. Tuyttens, and W. Verbeke. 2010. Citizens' views on farm animal welfare and related information provision: Exploratory insights from Flanders, Belgium. J. Agric. Environ. Ethics 23:551-569.

Vanhonacker, F., W. Verbeke, E. Van Poucke, S. Buijs, and F. A. M. Tuyttens. 2009. Societal concern related to stocking density, pen size and group size in farm animal production. Livest. Sci. $123: 16-22$.

Vellinga, T. V., M. H. A. de Haan, R. L. M. Schils, A. Evers, and A. van den Pol-van Dasselaar. 2011. Implementation of GHG mitigation on intensive dairy farms: Farmers' preferences and variation in cost effectiveness. Livest. Sci. 137:185-195.

von Keyserlingk, M. A. G., A. Barrientos, K. Ito, E. Galo, and D. M. Weary. 2012. Benchmarking cow comfort on North American freestall dairies: Lameness, leg injuries, lying time, facility design and management, for high-producing Holstein dairy cows. J. Dairy Sci. 95:7399-7408.

von Keyserlingk, M. A. G., J. Rushen, A. M. de Passillé, and D. M. Weary. 2009. Invited review: The welfare of dairy cattle - Key concepts and the role of science. J. Dairy Sci. 92:4101-4111.

Wada, Y. 2012. Non-sustainable groundwater sustaining irrigation. Global Water Forum. Accessed Mar. 5, 2013. http://www. globalwaterforum.org/2012/02/13/non-sustainable-groundwatersustaining-irrigation/.

Weary, D. M., C. S. Schuppli, and M. A. G. von Keyserlingk. 2011. Tail docking dairy cattle: Responses from an online engagement. J. Anim. Sci. 89:3831-3837.

Wheeler, M. B. 2007. Agricultural applications for transgenic livestock. Trends Biotechnol. 25:204-210.

Wolf, C. A., J. R. Black, and J. Hadrich. 2009. Upper Midwest dairy farm revenue variation and insurance implications. Agric. Finance Rev. 69:346-358.

Wolf, S. A. 2008. Professionalization of agriculture and distributed innovation for multifunctional landscapes and territorial development. Agric. Human Values 25:203-207.

Zaks, D. P. M., N. Winchester, C. J. Kucharik, C. C. Barford, S. Paltsev, and J. M. Reilly. 2011. Contribution of anaerobic digesters to emissions mitigation and electricity generation under U.S. climate policy. Environ. Sci. Technol. 45:6735-6742.

Zhou, Y., F. Zwahlen, Y. Wang, and Y. Li. 2010. Impact of climate change on irrigation requirements in terms of groundwater resources. Hydrogeol. J. 18:1571-1582.

Zucchetto, J., and G. Bickle. 1984. Energy and nutrient analyses of a dairy farm in central Pennsylvania. Energy in Agriculture 3:2947 . 